\title{
Metallodrug ranitidine bismuth citrate suppresses SARS-CoV-2 replication and relieves virus-associated pneumonia in Syrian hamsters
}

\author{
Shuofeng Yuan ${ }^{1,6}$, Runming Wang ${ }^{2,6}$, Jasper Fuk-Woo Chan ${ }^{1,3,6}$, Anna Jinxia Zhang1, \\ Tianfan Cheng ${ }^{4}{ }^{4}$, Kenn Ka-Heng Chik', Zi-Wei Ye1, Suyu Wang ${ }^{2}$, Andrew Chak-Yiu Lee', Lijian Jin ${ }^{4}$, \\ Hongyan Li ${ }^{2}$, Dong-Yan Jin $\mathbb{1}^{5}$, Kwok-Yung Yuen ${ }^{1,3 凶}$ and Hongzhe Sun ${ }^{2}{ }^{凶}$
}

\begin{abstract}
SARS-CoV-2 is causing a pandemic of COVID-19, with high infectivity and significant mortality'. Currently, therapeutic options for COVID-19 are limited. Historically, metal compounds have found use as antimicrobial agents, but their antiviral activities have rarely been explored. Here, we test a set of metallodrugs and related compounds, and identify ranitidine bismuth citrate, a commonly used drug for the treatment of Helicobacter pylori infection, as a potent anti-SARS-CoV-2 agent, both in vitro and in vivo. Ranitidine bismuth citrate exhibited low cytotoxicity and protected SARS-CoV-2-infected cells with a high selectivity index of 975. Importantly, ranitidine bismuth citrate suppressed SARS-CoV-2 replication, leading to decreased viral loads in both upper and lower respiratory tracts, and relieved virus-associated pneumonia in a golden Syrian hamster model. In vitro studies showed that ranitidine bismuth citrate and its related compounds exhibited inhibition towards both the ATPase $\left(\mathrm{IC}_{50}=0.69 \mu \mathrm{M}\right)$ and DNA-unwinding $\left(\mathrm{IC}_{50}=0.70 \mu \mathrm{M}\right)$ activities of the SARS-CoV-2 helicase via an irreversible displacement of zinc(II) ions from the enzyme by bismuth(III) ions. Our findings highlight viral helicase as a druggable target and the clinical potential of bismuth(III) drugs or other metallodrugs for the treatment of SARS-CoV-2 infection.
\end{abstract}

T he ongoing pandemic of coronavirus disease 2019 (COVID19), caused by the severe acute respiratory syndrome coronavirus 2 (SARS-CoV-2) ${ }^{1,2}$, is a global public health crisis with more than 30 million laboratory-confirmed cases, including over 1 million global deaths by the end of September $2020^{3}$. This pandemic poses an unprecedented challenge to the rapid identification of effective drugs for the prevention and treatment of this disease. Similar to other coronaviruses ${ }^{4}$, SARS-CoV-2 synthesizes a battery of viral enzymes and proteins that are essential for viral entry, replication and pathogenesis, including structural proteins and nonstructural proteins $(\mathrm{Nsp})^{5}$. Intervention at viral entry or replication allows vaccines or therapeutics to be effective ${ }^{6-10}$. Several enzymes ${ }^{11-13}$, including RNA-dependent RNA polymerase, 3-chymotrypsin-like protease and papain-like protease, may serve as promising targets of potential therapeutic drugs.

Repurposing drugs already in clinical use is the most practical approach for the rapid identification of antivirals for COVID-19, given the urgency and severity of the pandemic ${ }^{14,15}$. Remdesivir, a broad-spectrum antiviral drug, has been reported to show efficacy against SARS-CoV- $2^{16}$. It exhibits modest benefits, with the median time to patient recovery reduced by about 4 days from 15 days, as well as a slightly reduced mortality rate ${ }^{17}$. However, the drug's global shortage, relatively high price and lack of significant clinical benefits in patients with severe COVID-19 have so far limited its widespread use $^{18}$. Dexamethasone was recently shown to reduce the mortality rate of patients, especially among those with severe COVID-19 who required mechanical ventilation ${ }^{19}$. However, dexamethasone may be associated with immunosuppression and opportunistic nosocomial infections, and has shown limited benefits in patients with mild COVID-19 not requiring respiratory support ${ }^{19}$. We have recently reported the clinical benefits of the triple combination therapy of interferon- $\beta 1 b$, lopinavir-ritonavir and ribavirin in the treatment of patients with COVID-1920. However, some patients developed side effects, such as liver dysfunction and gastrointestinal upset. Other ongoing clinical trials on a series of antiviral agents are trying hard to improve the clinical outcomes of patients ${ }^{2,10}$. Therefore, more efforts to evaluate a wider spectrum of clinically approved drugs by alternative strategies are urgently needed.

In the effort to repurpose metallodrugs and their related compounds as COVID-19 treatments, we have discovered that ranitidine bismuth citrate (RBC), a commonly used drug with a safe and comprehensive pharmacological profile, potently inhibits SARS-CoV-2 replication in human and animal cell lines and in an established golden Syrian hamster model by disrupting the functions of helicase and possibly other essential viral enzymes. Our findings suggest $\mathrm{RBC}$ and other metallodrugs as potential therapies for COVID-19.

\footnotetext{
'State Key Laboratory of Emerging Infectious Diseases, Carol Yu Centre for Infection, Department of Microbiology, Li Ka Shing Faculty of Medicine, The University of Hong Kong, Pokfulam, Hong Kong Special Administrative Region, Hong Kong, China. ${ }^{2}$ Department of Chemistry, State Key Laboratory of Synthetic Chemistry, CAS-HKU Joint Laboratory of Metallomics on Health and Environment, The University of Hong Kong, Pokfulam, Hong Kong Special Administrative Region, Hong Kong, China. ${ }^{3}$ Department of Clinical Microbiology and Infection Control, The University of Hong Kong-Shenzhen Hospital, Shenzhen, Guangdong Province, China. ${ }^{4}$ Faculty of Dentistry, The University of Hong Kong, Pokfulam, Hong Kong Special Administrative Region, Hong Kong, China. ${ }^{5}$ School of Biomedical Sciences, Li Ka Shing Faculty of Medicine, The University of Hong Kong, Pokfulam, Hong Kong Special Administrative Region, Hong Kong, China. ${ }^{6}$ These authors contributed equally: Shuofeng Yuan, Runming Wang, Jasper Fuk-Woo Chan. 凶e-mail: kyyuen@hku.hk; hsun@hku.hk
} 


\section{Results}

Selected metallo-compounds exhibit potent activity against SARS-CoV-2 in vitro. Historically, metal compounds have been used as antimicrobial agents. However, their antiviral activities have not been explored extensively. Our earlier studies demonstrated that bismuth drugs and related compounds exhibit excellent antiviral activity against SARS-CoV ${ }^{21}$. Building on these results, we selected six metal compounds-two bismuth(III) citrate-based drugs (colloidal bismuth subcitrate (CBS) and RBC, two bismuth(III) porphyrins (Bi(TPP) (TPP, tetraphenylporphyrinate) and $\mathrm{Bi}(\mathrm{TPyP})$ (TPyP, tetra(4-pyridyl)porphyrin)), one $\mathrm{Au}(\mathrm{I})$-based drug (Auranofin), as well as its active derivative, chloro(triethylphosphine) gold(I) $\left(\mathrm{Au}\left(\mathrm{PEt}_{3}\right) \mathrm{Cl}\right)$ - to carry out a primary evaluation against SARS-CoV-2 in vitro (Extended Data Fig. 1). The 50\% cytotoxicity concentrations $\left(\mathrm{CC}_{50}\right)$ of these compounds in monkey kidney Vero E6 cells were determined to be $3,254 \pm 21 \mu \mathrm{M}$ for CBS, $2,243 \pm 43 \mu \mathrm{M}$ for $\mathrm{RBC},>400 \mu \mathrm{M}$ for both $\mathrm{Bi}(\mathrm{TPP})$ and $\mathrm{Bi}(\mathrm{TPy})$, $14.2 \pm 1.3 \mu \mathrm{M}$ for auranofin and $13.5 \pm 1.8 \mu \mathrm{M}$ for $\mathrm{Au}\left(\mathrm{PEt}_{3}\right) \mathrm{Cl}$ (Extended Data Fig. 2). The four bismuth(III) compounds were prioritized for further evaluation of their $\mathrm{CC}_{50}$ values in human colorectal Caco- 2 cells because of their promisingly low cytotoxicity compared with the $\mathrm{Au}(\mathrm{I})$-based drugs, resulting in similar $\mathrm{CC}_{50}$ values ranging from 400 to $3,740 \mu \mathrm{M}$ (Extended Data Fig. 2). To evaluate their antiviral potency, the half-maximal effective doses $\left(\mathrm{EC}_{50}\right)$ of the bismuth(III) compounds were determined at low micromolar levels as $4.6 \pm 0.4 \mu \mathrm{M}$ for CBS, $2.3 \pm 0.5 \mu \mathrm{M}$ for RBC, $3.9 \pm 1.2 \mu \mathrm{M}$ for $\mathrm{Bi}(\mathrm{TPP})$ and $7.5 \pm 0.9 \mu \mathrm{M}$ for $\mathrm{Bi}(\mathrm{TPyP})$. Remarkably, addition of all four bismuth(III) compounds at $1 \mathrm{~h}$ post infection (h.p.i.) reduced viral RNA loads in both Vero E6 and Caco-2 cells in a dose-dependent manner (Fig. 1). In non-toxic concentrations, CBS and $\mathrm{RBC}$ exhibited more potent anti-SARS-CoV-2 activity than $\mathrm{Bi}(\mathrm{TPP})$ and $\mathrm{Bi}(\mathrm{TPy})$, as evidenced by the maximal $\sim 2-\log$ versus 1-log viral load reduction in the Vero E6 cell lysate (Fig. 1a-d), $\sim 3-\log$ versus $\sim 2-\log$ reduction in the Caco-2 cell lysate (Fig. 1e-h), $\sim 4-\log$ versus $\sim 3-\log$ reduction in the Vero E6 cell culture supernatant (Fig. 1i-1) and $\sim 4$-log versus $\sim 3-\log$ reduction in the Caco- 2 cell culture supernatant (Fig. $1 \mathrm{~m}-\mathrm{p})$.

Importantly, bismuth(III) drugs/compounds greatly inhibited SARS-CoV-2, as evidenced by the markedly decreased expression of viral nucleoprotein in the drug-treated cells when compared with the dimethyl sulfoxide (DMSO)-treated group (Fig. 2a-f). To investigate which steps of the SARS-CoV-2 replication cycle were interrupted by the selected drug compounds, we performed a time-of-drug-addition assay by treating virus-infected cells with each compound at different time points, followed by measurements of viral titre after 9h.p.i., when the first round of progeny virions were detectable in the cell culture supernatant. (Fig. 2g,h). Intriguingly, addition of $\mathrm{Bi}(\mathrm{TPyP})$ during pre-treatment or co-incubation of cells significantly suppressed virus replication, whereas no detectable effect was found when $\mathrm{Bi}(\mathrm{TPy})$ was maintained after virus entry, indicating that $\mathrm{Bi}(\mathrm{TPyP})$ may interfere with SARS-CoV-2 attachment to the cellular surface. RBC did not affect virus replication when added during the pre-incubation stage, whereas it reduced viral loads by $\sim 2 \log$ when added during co-incubation and post-entry stages, suggesting that RBC is a multiple-target drug that acts during virus entry/internalization or early events after viral entry. To validate this, the interruption of virus entry by $\mathrm{RBC}$ and $\mathrm{Bi}(\mathrm{TPy})$ was confirmed by a pseudotyped virus infection assay, showing that the percent virus entry was lowered by $\sim 45 \%$ and $53 \%$ by RBC and Bi(TPyP), respectively (Fig. $2 \mathrm{i}$ ). Apparently, both CBS and Bi(TPP) function at post-entry stages. In summary, we have demonstrated the vulnerability of SARS-CoV-2 to treatment with bismuth(III)-based drugs.

Therapeutic treatment with RBC mitigates SARS-CoV-2 disease. $\mathrm{RBC}$ is a commonly clinically used drug for the treatment of Helicobacter pylori infection and peptic ulcer and has a well-documented safety profile ${ }^{22}$. RBC is composed of bismuth citrate and ranitidine ${ }^{23}$. We showed that ranitidine alone lacked significant anti-SARS-CoV-2 effect (Extended Data Fig. 3), whereas RBC exhibited a much higher selectivity index (975) than bismuth alone. We therefore used RBC for in vivo antiviral evaluation. Previous pharmacokinetics studies have shown that $\mathrm{RBC}$ has a relatively rapid absorption $\left(t_{\max }(\right.$ bismuth $) \approx 0.5 \mathrm{~h}, t_{\max }($ ranitidine $\left.) \approx 2.5 \mathrm{~h}\right)$ and small renal clearance $\left(\mathrm{CL}_{\mathrm{r}}\right.$ (bismuth $\left.) \approx 40 \mathrm{ml} \mathrm{min}^{-1}\right)$, with pharmacokinetic behaviours linear within the dose range ${ }^{24}$. We recently established an in vivo model to simulate the clinical and pathological manifestations of COVID-19 in golden Syrian hamsters, which serve as a suitable tool to study antiviral effects and disease pathogenesis $^{25}$. In our pilot study, intraperitoneal injection of RBC at a dose of $150 \mathrm{mg}$ per kg bogy weight per day showed negligible toxicity in the animals. Remdesivir was included as a positive control drug and dosed at $15 \mathrm{mg}$ per $\mathrm{kg}$ body weight per day based on its effective dosage in SARS-CoV-infected mice ${ }^{26}$. In the present study, hamsters were intranasally challenged with $10^{4}$ plaque-forming units (p.f.u.) SARS-CoV-2 before four consecutive daily dosages beginning at 6 h.p.i. Expectedly, the DMSO-treated control hamsters developed the clinical signs of lethargy, ruffled fur, hunched back posture and rapid breathing starting from 2 days post infection (d.p.i.), whereas the hamsters treated with either RBC or remdesivir did not develop any clinical signs. At 4 d.p.i., when the viral loads and histopathological changes were expected to be the most prominent in this established animal model, we examined whether RBC conferred protection against SARS-CoV-2 challenge by reducing the viral loads in the upper (nasal turbinate) and lower (lung) respiratory tract tissues. Apparently, RBC decreased the viral RNA load in both nasal turbinate $(P<0.05)$ and lung tissues $(P<0.01)$ by $\sim 1$ to $1.5 \log$ (Fig. 3a). Consistently, suppression of live SARS-CoV-2 viral particles in the respiratory tract was confirmed in both the RBC- and remdesivir-treated hamsters (Fig. 3b).

Increased secretion of pro-inflammatory cytokines and chemokines is associated with disease severity in patients with COVID- $19^{27}$. To ascertain if the therapeutic effect of RBC relieved virus-induced cytokine dysregulation, we determined the expression levels of interleukin-6 (IL-6), interleukin-10 (IL-10) and tumour necrosis factor alpha (TNF- $\alpha$ ), which are prognostic markers for severe COVID-19, as well as other major pro-inflammatory cytokines and chemokines including interferon- $\gamma$ (IFN- $\gamma$ ), C-C motif chemokine ligand 22 (CCL22) and C-C chemokine receptor type 4 (CCR4) $)^{28}$. Intriguingly, mRNA expression of IFN- $\gamma(P<0.05)$, IL-6 $(P<0.01)$, IL-10 $(P<0.001)$ and CCR4 $(P<0.05)$ were remarkably diminished in the hamsters treated with RBC, whereas those treated with remdesivir generally had lower but statistically non-significant (except IL-6) changes compared with DMSO-treated animals (Fig. 3c). This may be ascribable to an immunomodulatory capability on the pathogen-disturbed inflammatory response of RBC in mammalian cells, in addition to its direct antiviral effects ${ }^{29}$.

To provide clear monitoring of the disease, histological examination of haemotoxylin and eosin (H\&E)-stained lung tissues was carried out at 4 d.p.i. Significant amelioration of lung damage was observed after RBC treatment (Fig. 3d-g). In the DMSO control group, a large area of consolidation and massive alveolar space mononuclear cell infiltration and exudation were identified in animal lungs, as well as moderate severity of bronchiolar epithelial cell death (Fig. 3d). In addition, endothelium and vessel wall mononuclear cells infiltration was observed in the pulmonary blood vessels (magnified images, Fig. 3d). Lung tissues in the remdesivir treatment group exhibited improved morphology but a mild degree of bronchiolar wall infiltration and vessel wall infiltration (Fig. 3e). After RBC treatment, however, only slight alveolar wall thickening and mild peribronchiolar infiltration were detected, without visible blood vessel inflammatory changes (Fig. 3f). Immunofluorescence 

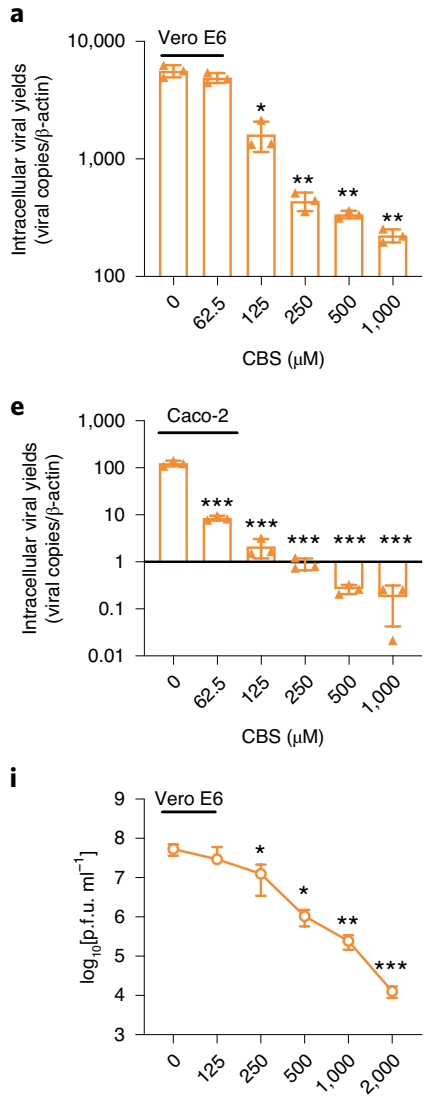

CBS ( $\mu \mathrm{M})$

m

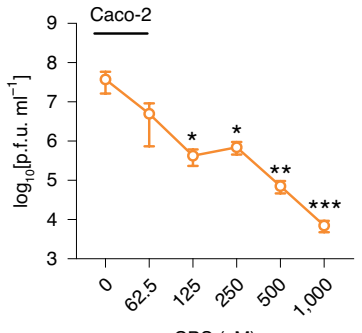

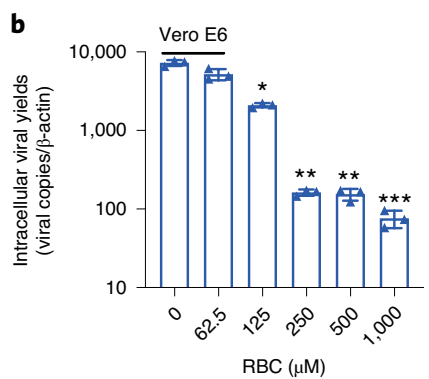

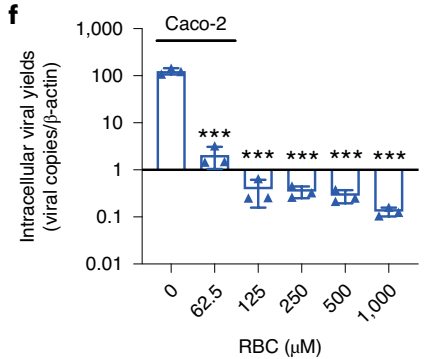

j
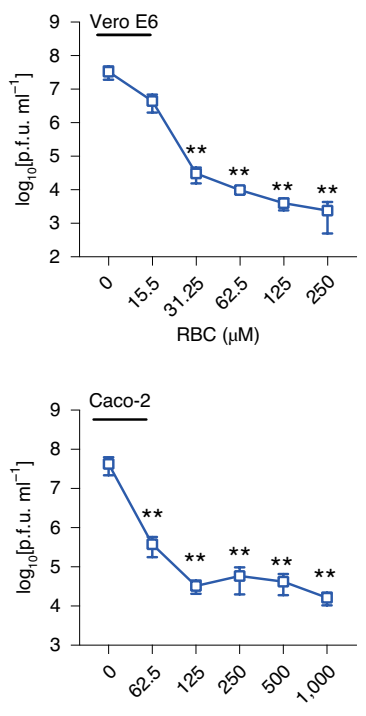
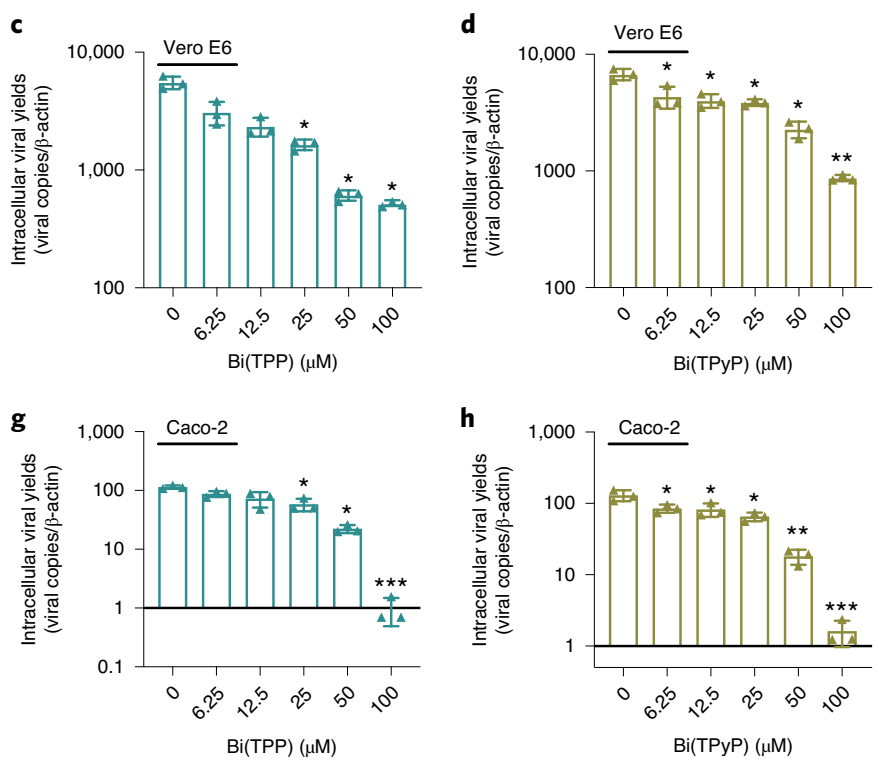

k
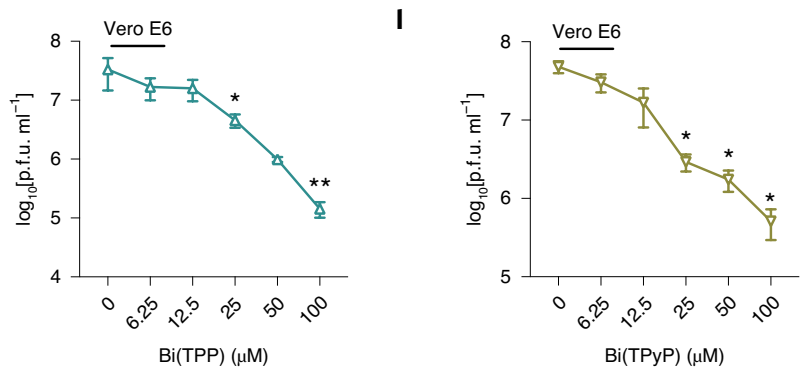

o

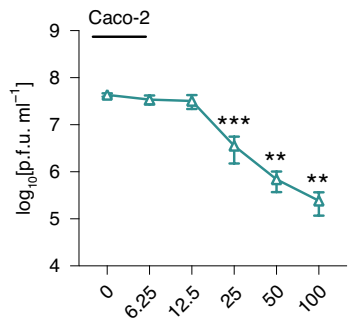

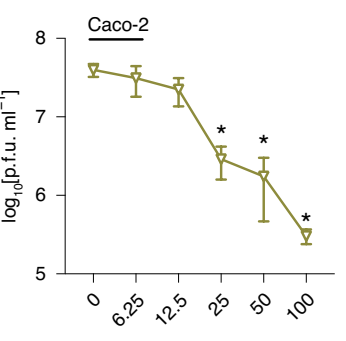

Fig. 1 In vitro antiviral activity of the selected compounds. Vero E6 and Caco-2 cells were infected with SARS-CoV-2 (multiplicity of infection (MOI) $=0.1)$ and treated with different concentrations of RBC and related compounds, as indicated. $\mathbf{a}-\mathbf{h}$, Intracellular viral loads were detected at $48 \mathrm{~h} . \mathrm{p} . \mathrm{i}$. and normalized by human $\beta$-actin in Vero E6 cells (a-d) and Caco-2 cells (e-h). i-p, Virus copies in the cell culture supernatant were determined at 48 h.p.i. by qualitative polymerase chain reaction with reverse transcription ( $\mathrm{RRT}-\mathrm{PCR}$ ) in Vero E6 cells (i-I) and Caco-2 cells ( $\mathbf{m}-\mathbf{p})$. Measures of drug concentration were based on metal content. All results are shown as mean \pm s.d. Statistical significance was calculated using an unpaired two-tailed Student's $t$-test $(n=3) ;{ }^{\star} P<0.05$, ${ }^{*} P<0.01$ and ${ }^{* \star} P<0.001$ when compared with vehicle control $(0 \mu \mathrm{M})$. All experiments were performed in triplicate and repeated twice for confirmation.

staining indicated diminished $\mathrm{N}$ protein expression in alveolar tissue, being mainly expressed in focal bronchiolar epithelial cells of hamster lungs after treatment with remdesivir and RBC (Fig. 3h-j). Collectively, we thus demonstrate the effectiveness of RBC by disrupting the SARS-CoV-2 replication cycle and virus-associated pneumonia in vivo.

RBC is a potent irreversible inhibitor of SARS-CoV-2 helicase in vitro. We previously demonstrated that bismuth(III) drugs function via a 'shotgun' mechanism, that is, targeting multiple biological pathways through binding to key proteins, in particular zinc-containing proteins $s^{30,31}$. Given that zinc is frequently incorporated as zinc-fingers or zinc-binding domains in several essential Nsp of coronavirus (for example, PLpro cysteine protease ${ }^{32}$, RNA-dependent RNA polymerase ${ }^{13}$ and helicase ${ }^{33}$ ), we hypothesized that bismuth(III) may functionally inactivate these enzymes, thus prohibiting SARS-CoV-2 viral replication. As a proof of principle, we chose SARS-CoV-2 helicase as a feasible target to investigate whether bismuth(III) compounds could inactivate the enzyme. Helicases are motor proteins that serve to convert nucleoside triphosphate to nucleoside diphosphate and inorganic phosphate during single-stranded nucleic acid translocation and double-stranded (ds) nucleic acid separation and unwinding of both dsRNA and dsDNA with a $5^{\prime}$-ss tail along the polarity of $5^{\prime}$ to $3^{\prime}$ (refs. ${ }^{34,35}$ ). Accumulative studies have shown that an RNA virus will neither replicate nor synthesize its RNA genome without a functional helicase $^{36}$. Unlike the structural proteins of coronaviruses, helicases (Nsp13) have been shown to be conserved among closely related coronavirus species (for example, SARS- and MERS-Nsp13) ${ }^{33,37}$, suggesting the potential of SAR-CoV-2 helicase inhibitors to be a 
a

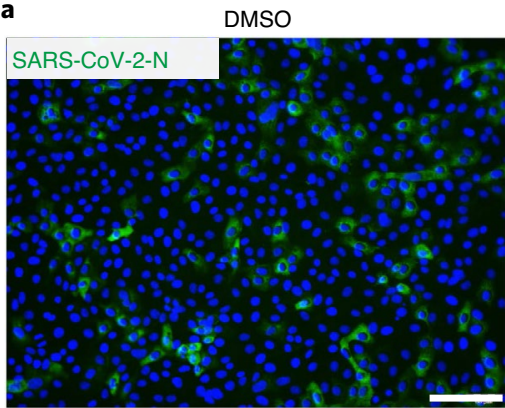

d

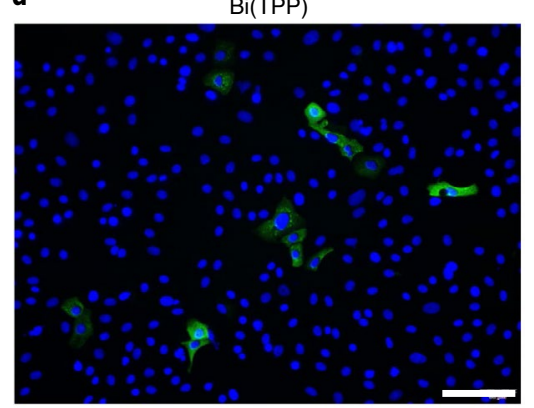

b

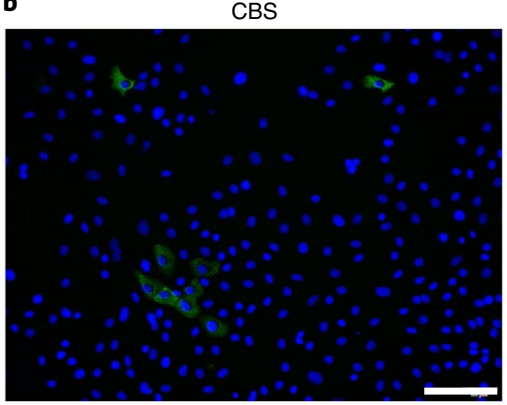

e

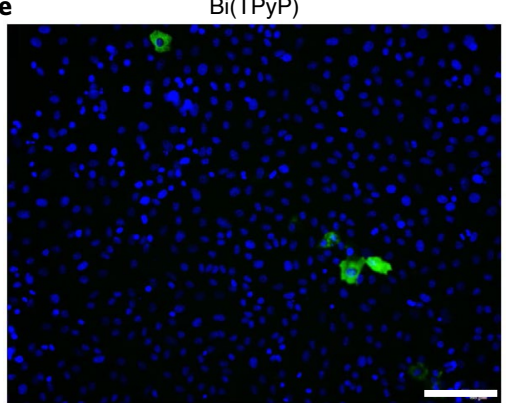

C

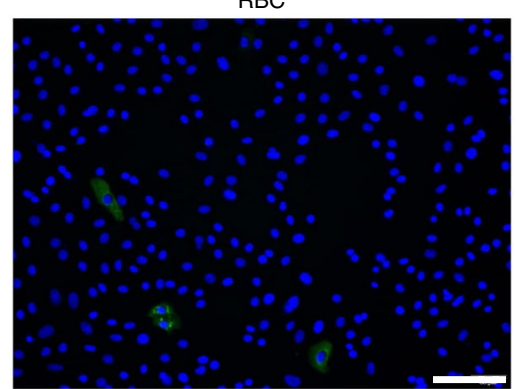

f
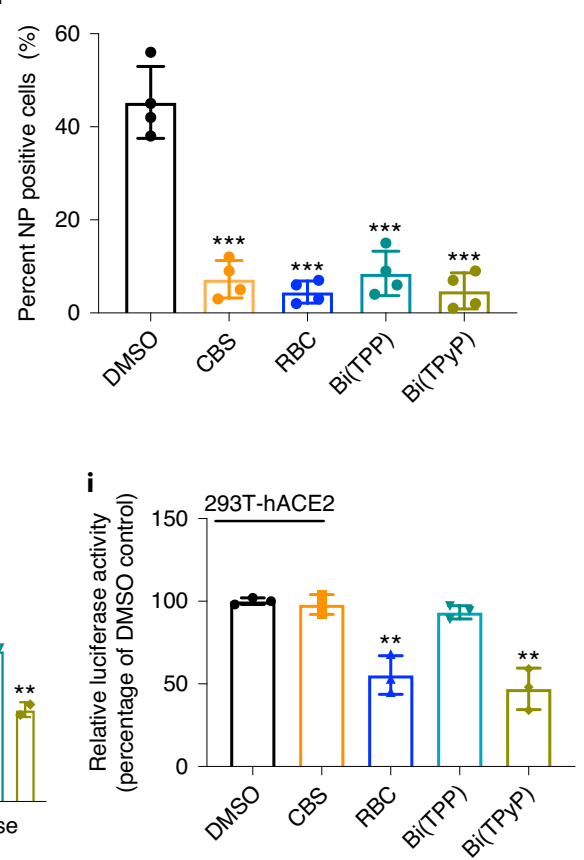

g

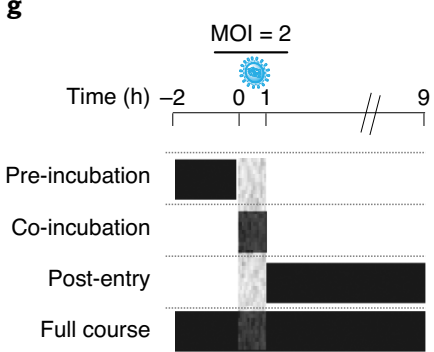

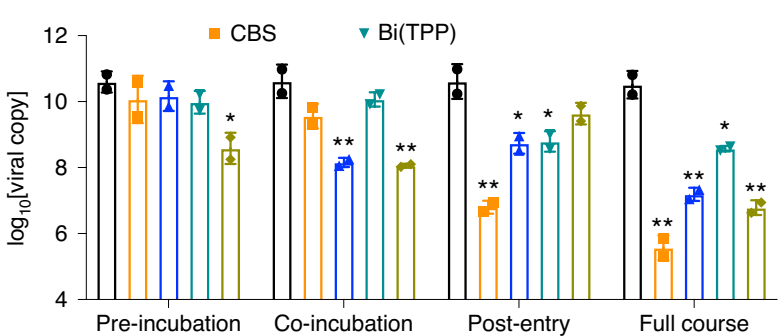

- DMSO $\triangle \mathrm{RBC} \quad$ Bi(TPyP)

Post-entry
Full course

Fig. 2 | Stage of action of the antiviral compounds. a-e, Immunofluorescence staining images showing the anti-SARS-CoV-2 effects of the selected drug compounds. Fixation and staining were performed on SARS-CoV-2-infected ( $\mathrm{MOI}=0.1)$ Vero E6 cells after treatment with DMSO control (a), CBS (b), RBC (c), Bi(TPP) (d) and Bi(TPyP) (e) for 24h. The nucleocapsid protein of SARS-CoV-2 (SARS-CoV-2-N) antigens and cell nuclei (DAPI) were stained in green and blue, respectively. Scale bars, $100 \mu$ m. f, Quantification of antigen-positive cells from randomly selected $800 \times 800$-pixel fields $(n=4)$ over two independent experiments (one-way analysis of variance, ANOVA). NP indicates the nucleocaspid protein of SARS-CoV-2. g,h, A time-of-drug-addition assay, performed to determine the steps of the viral replication cycle targeted by each of the four drug compounds. In $\mathbf{g}$, the scheme shows the experimental design, indicating the period of cell-compound incubation. Virus absorption was performed at $\sim 0-1 \mathrm{~h}(\mathrm{MOI}=2)$, followed by replacement of fresh medium supplemented with the tested drug or DMSO. In $\mathbf{h}$, bar charts show the virus yields in the supernatant of all groups, quantified by qRT-PCR at 9 h.p.i. One-way ANOVA was used to compare the treatment groups with the negative control group (0 $\mu$ M, 0.1\% DMSO). i, HEK293-hACE2 stable cells were infected with pseudo-SARS-CoV-2-Luc in the presence of DMSO or drug compounds, as indicated $(n=3)$. Luciferase activity was measured at 48 h.p.i. and normalized as percent of DMSO control. One-way ANOVA was used. Measures of drug concentration were based on metal content. All results are shown as mean \pm s.d. of the indicated number of biological repeats. Statistical significance was calculated using an unpaired two-tailed Student's $t$-test, ${ }^{\star} P<0.05,{ }^{\star \star} P<0.01$ and ${ }^{\star \star \star} P<0.001$. All experiments were replicated twice for confirmation.

new category of antiviral therapy for COVID-19 and respiratory infections caused by other coronaviruses.

To explore the potential role of RBC on SARS-CoV-2 helicase, we first overexpressed and purified the full-length Nsp13 protein (Extended Data Fig. 4), which contains an N-terminal zinc-binding domain (ZBD) and a C-terminal helicase domain (HEL). By carrying out a typical phosphate release assay, we first examined whether bismuth(III) compounds inhibit the ATPase activity of SARS-CoV-2 helicase $^{38}$. The phosphate released due to ATP hydrolysis is presented as a relative percentage of ATPase activity with or without the addition of bismuth(III) compounds. As shown in Fig. 4a-d, ATPase activity was significantly decreased as the concentration of bismuth(III) increased, with the activity being inhibited, ultimately, over $90 \%$. The half-maximum inhibitory concentration $\left(\mathrm{IC}_{50}\right)$ values were calculated to be $1.88 \pm 0.12,0.69 \pm 0.12,2.39 \pm 0.02$ and $4.68 \pm 1.39 \mu \mathrm{M}$ for $\mathrm{CBS}, \mathrm{RBC}, \mathrm{Bi}(\mathrm{TPP})$ and $\mathrm{Bi}(\mathrm{TPy})$, respectively (Extended Data Fig. 5), indicative of effective inhibition of the ATPase activity of SARS-CoV-2 helicase by RBC and relevant bismuth(III) compounds.

We next investigated the effects of the four bismuth(III) compounds on the duplex-unwinding activity of SARS-CoV-2 helicase by an established fluorescence resonance energy transfer (FRET)-based assay ${ }^{21}$. Because both dsDNA and dsRNA could be unwound by SARS-CoV-2 helicase ${ }^{39}$, for practical reasons we chose dsDNA as the substrate to assess the inhibitory activity of the tested compounds. The DNA-duplex substrate was prepared by annealing 
a

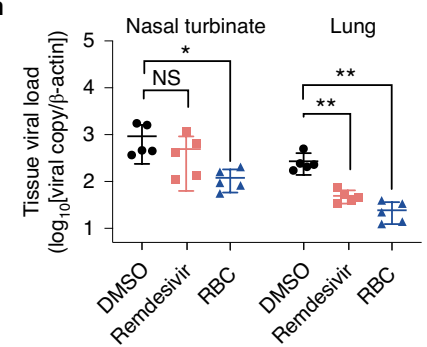

b
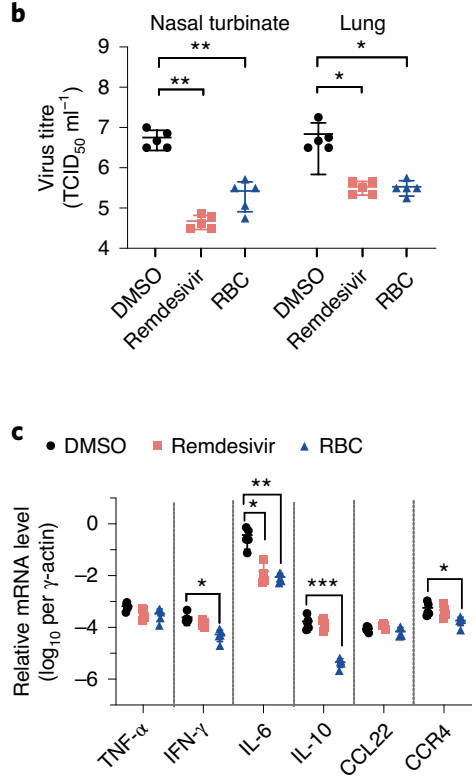

\section{d}

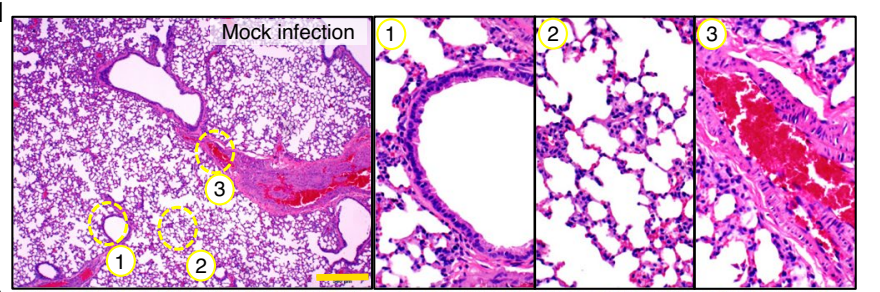

$\mathrm{e}$

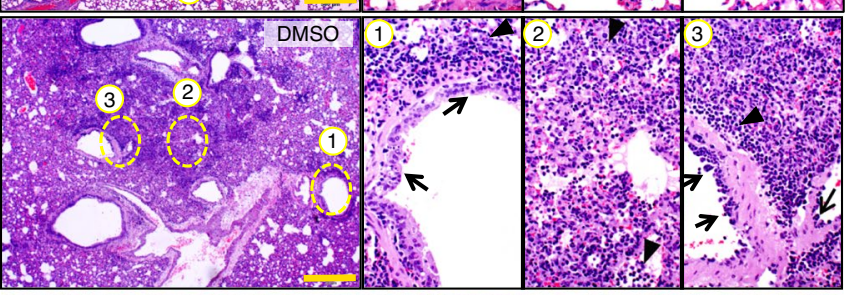

$\mathbf{f}$

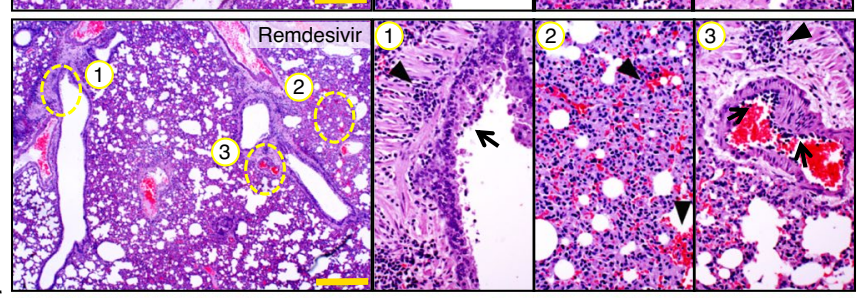

g

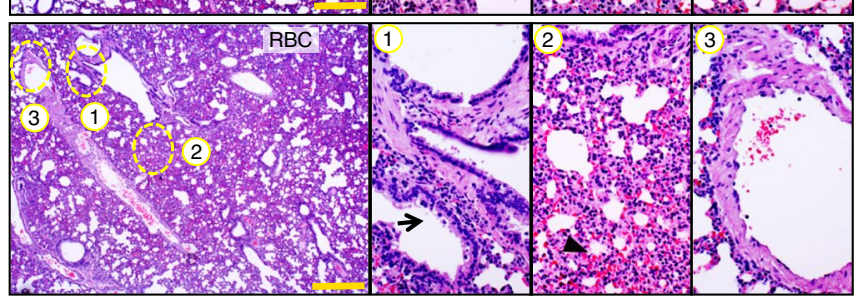

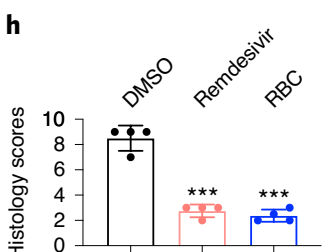
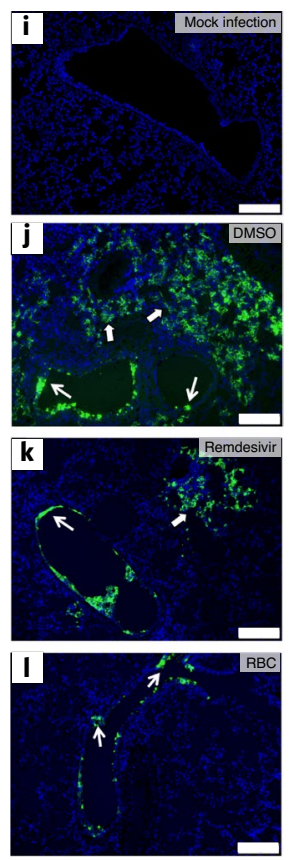

Fig. $\mathbf{3}$ | In vivo antiviral activity of RBC. a,b, Hamsters $(n=5)$ were intranasally inoculated with $10^{4}$ p.f.u. of SARS-CoV-2 and intraperitoneally given either DMSO (vehicle control), RBC $\left(150 \mathrm{mg} \mathrm{kg}^{-1}\right)$ or remdesivir $\left(15 \mathrm{mg} \mathrm{kg}^{-1}\right)$ for four consecutive days, with the first dose given at 6 h.p.i. At 4 d.p.i., respiratory tissue viral yields in the nasal turbinate and lung tissues of the hamsters were determined by qRT-PCR assay (a) and median tissue culture infective dose $\left(T_{C I D}\right)$ assay $(\mathbf{b})$, respectively. c, Representative chemokine and cytokine assessment of the lung tissues $(n=3)$ of the indicated groups, as detected in the lung tissue homogenate at 4 d.p.i. The results are shown as mean \pm s.d. ${ }^{\star} P<0.05,{ }^{\star \star} P<0.01$ and ${ }^{\star \star \star} P<0.001$ when compared with the DMSO group. NS, not significant. One-way ANOVA was used. d,e, Images and scoring of hamster lung histopathological changes at 4 d.p.i. The representative images of H\&E-stained lung tissue section from mock-infected hamster (d) and infected hamster treated with DMSO showing diffuse lung tissue consolidation with alveolar infiltration and exudation (e). Numbered circled areas are shown in magnified images to the right, illustrating (1) bronchiolar epithelium cell death (arrow) and peribronchiolar mononuclear cell infiltration (arrowhead); (2) destruction of alveoli with massive alveolar space infiltration (arrowhead); (3) two blood vessels showing intra-endothelium infiltration (arrows) and perivascular infiltration (arrowhead). $\mathbf{f}, \mathbf{g}$, Representative images of H\&E-stained lung tissue section from hamsters treated with remdesivir (f) and RBC ( $\mathbf{g}$ ), showing alleviated infiltration, as shown in alveolar and blood vessels. Scale bar, $500 \mu \mathrm{m}(\mathbf{d}-\mathbf{g})$. h. Histological score indicating lung histopathological severity in each group. The scoring method is detailed in the Methods. Data are presented as mean \pm s.d. of four randomly selected slides from each group. Unpaired two-tailed Student's $t$-test, ${ }^{\star \star \star \star} P<0.001$ when compared with the DMSO control group. The histological score of mock infection was set as zero. $\mathbf{i}-\mathbf{I}$, Representative images of the viral N protein distribution in lung tissue sections from groups of uninfected hamsters (i) and infected hamsters treated with DMSO (j), remdesivir (k) and RBC (I), at 4 d.p.i. Viral N protein expression is shown in diffuse alveolar areas (thick white arrows) and in the focal bronchiolar epithelial cells (thin white arrows). These representative images were selected from a pool of over 30 images captured in three randomly selected hamsters per group. Scale bar, $200 \mu \mathrm{m}$ (i-I).

an oligomer with a $\mathrm{Cy} 3$ fluorophore at the $3^{\prime}$ end and a BHQ2 quencher at the $5^{\prime}$ end. The proteins and DNA duplex were equilibrated in the presence of varying concentrations of bismuth compounds before fluorescence titration. In the absence of bismuth(III) compounds, the signal intensity of the DNA duplex increased drastically due to unwinding of the Cy3 strand from the DNA duplex via helicase. By contrast, the fluorescence increased much less evidently at increasing concentrations of bismuth(III) compounds, indicative of the inhibition of duplex unwinding in a dose-dependent manner (Fig. $4 \mathrm{e}-\mathrm{h}$ ). Similarly, the $\mathrm{IC}_{50}$ values of the compounds against duplex-unwinding activity of the enzyme were measured to be $1.24 \pm 0.02 \mu \mathrm{M}$ for $\mathrm{CBS}, 0.74 \pm 0.13 \mu \mathrm{M}$ for $\mathrm{RBC}, 3.69 \pm 0.26 \mu \mathrm{M}$ for
$\mathrm{Bi}(\mathrm{TPP})$ and $2.64 \pm 0.16 \mu \mathrm{M}$ for Bi(TPyP) (Extended Data Fig. 5). Significantly, this inhibition was irreversible, as the supplementation of up to 50 molar equivalents of zinc(II) to bismuth-bound SARS-CoV-2 helicase only led to $\sim 6 \%$ ATPase activity and $\sim 13 \%$ duplex-unwinding activity being restored, indicating a limited ability of zinc(II) to compete with bismuth(III) for SARS-CoV-2 helicase (Fig. 4i,j). Increasing concentrations of RBC barely changed the the maximum velocity $\left(V_{\max }\right)$ value of $42.05 \pm 2.78 \mathrm{mM} \mathrm{s}^{-1}$, whereas an increase in apparent Michaelis-Menten constant $\left(K_{\mathrm{m}}\right)$ from 5.51 to $12.74 \mathrm{mM}$ was observed, indicative of a competitive inhibition on ATPase activity of SARS-CoV-2 helicase (Fig. 4k,l). The inhibition constant $\left(K_{\mathrm{i}}\right)$ of RBC against helicase ATPase activity was 

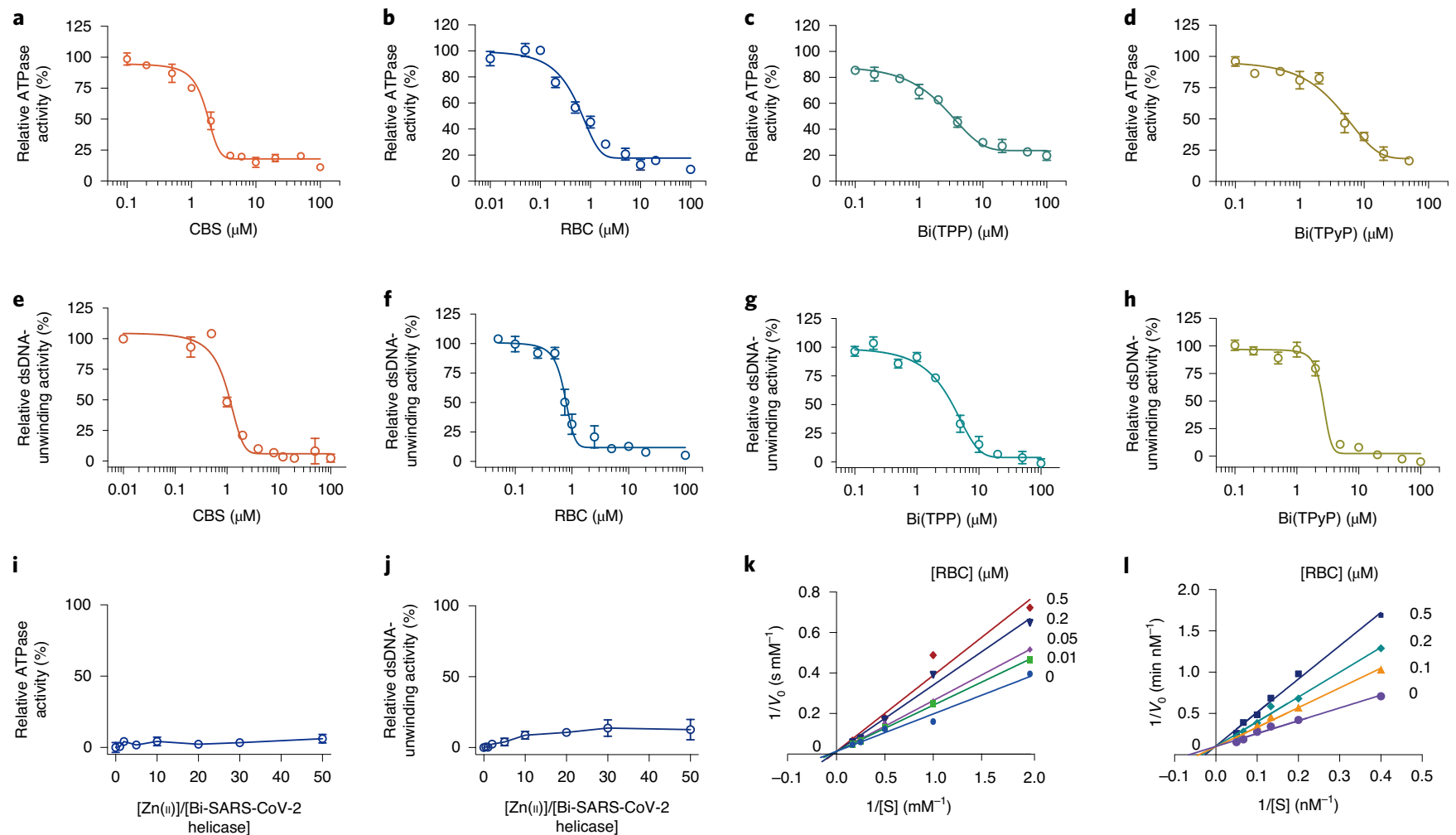

Fig. 4 | Inhibitory activity profiles of RBC against SARS-CoV-2 helicase. a-d, Inhibition of the ATPase activity of the SARS-CoV-2 helicase by CBS (a), RBC (b), $\mathrm{Bi}(\mathrm{TPP})(\mathbf{c})$ and $\mathrm{Bi}(\mathrm{TPy})$ (d), at varying concentrations as indicated. e-h, Titration of the DNA-unwinding activity of the SARS-CoV-2 helicase by CBS (e), RBC (f), Bi(TPP) (g) and Bi(TPyP) (h), at varying concentrations, as indicated by a FRET-based assay. In a-h, the data are expressed as a percentage of the control reaction in the absence of inhibitors. Dose-response curves for half-maximum inhibitory concentration $\left(\mathrm{IC}_{50}\right)$ values were determined by nonlinear regression. $\mathbf{i}, \mathbf{j}$, Restoration of the activity of ATPase (i) and the DNA-unwinding activity of Bi-SARS-CoV-2 helicase (j) following supplementation with various ratios of zinc(II) as indicated. All assays in $\mathbf{a}-\mathbf{j}$ were performed in triplicate and the data are presented as mean \pm s.d. $\mathbf{k}, \mathbf{I}$, Lineweaver-Burk plots showing the kinetics of inhibition on ATPase activity ( $\mathbf{k})$ and DNA-unwinding activity of SARS-CoV-2 helicase (I) by RBC. The effect of the inhibitors on the enzyme was determined from the double reciprocal plot of $1 /$ rate $(1 / V)$ versus $1 /$ substrate concentration in the presence of varying concentrations of RBC. The $K_{\mathrm{i}}$ values were calculated by the intersection of the curves obtained by plotting $1 / V$ versus inhibitor concentration for each substrate concentration. In $\mathbf{a}-\mathbf{i}$, measures of drug concentration are based on metal content. The mean value of three replicates is shown and error bars indicate \pm s.d. of $n=3$ independent replicates. Statistical significance was calculated using an unpaired two-tailed Student's $t$-test. All experiments were repeated twice for confirmation.

estimated to be $0.97 \pm 0.11 \mu \mathrm{M}$. Similarly, RBC exhibited a competitive mode of inhibition on helicase duplex-unwinding activity, with an unchanged $V_{\max }$ value of $20.53 \pm 1.56 \mathrm{nM} \mathrm{min}^{-1}$, increasing $K_{\mathrm{m}}$ values from $42.21 \mathrm{nM}$ to $91.77 \mathrm{nM}$ and a $K_{\mathrm{i}}$ value estimated as $0.39 \pm 0.07 \mu \mathrm{M}$. Our combined data demonstrate that RBC serves as a potent irreversible inhibitor of SARS-CoV-2 helicase.

RBC binds to SARS-CoV-2 helicase and releases zinc ions from ZBD in vitro. Structural analysis showed that SARS coronavirus helicase contains three canonical zinc-fingers, including zinc-finger 1 (Cys5, Cys8, Cys26, Cys29), zinc-finger 2 (Cys16, Cys19, His33, His39) and zinc-finger 3 (Cys50, Cys55, Cys72, His75) ${ }^{33}$. Given the high thiophilicity of bismuth(III), we therefore investigated, by UVvis spectroscopy, whether bismuth(III) competes with the zinc(II) in zinc-finger sites. To rule out the interference of ranitidine in $\mathrm{RBC}$, a colourless bismuth compound, $\mathrm{Bi}(\mathrm{NTA})$, was prepared and then titrated to the apo-form of SARS-CoV-2 helicase. Addition of bismuth(III) to apo-SARS-CoV-2 helicase led to the appearance and increase of an absorption band at $\sim 340 \mathrm{~nm}$, a characteristic of the $\mathrm{Bi}-\mathrm{S}$ ligand-to-metal charge transfer (LMCT) band. As shown in Fig. 5a, the absorption intensities at $340 \mathrm{~nm}$ increased and then plateaued at a molar ratio of $[\mathrm{Bi}(\mathrm{III})] /[\mathrm{SARS}-\mathrm{CoV}-2$ helicase] of 3 , with a dissociation constant $\left(K_{\mathrm{d}}\right)$ of $1.38 \pm 0.05 \mu \mathrm{M}$ as determined by fitting data with the Ryan-Weber nonlinear equation. The results suggest that three bismuth(III) ions bind per SARS-CoV-2 helicase and the cysteine residues in zinc-finger sites are involved in the binding.

Next, using inductively coupled plasma mass spectrometry (ICP-MS), we asked whether binding of bismuth(III) to SARS-CoV-2 helicase resulted in zinc(II) release. Utilizing equilibrium dialysis, we showed that $\sim 3.46$ molar equivalents of $\mathrm{Zn}$ (II) bound to SARS-CoV-2 helicase. The titration of RBC to SARS-CoV-2 helicase resulted in a decrease in the stoichiometry of $\mathrm{Zn}$ (II) ions, accompanied by an increase in that of bismuth(III) to SARS-CoV-2 helicase; eventually, $\sim 2.90$ molar equivalents of $\mathrm{Zn}$ (II) were displaced, whereas $\sim 2.73$ molar equivalents of bismuth(III) bound to the enzyme (Fig. 5b). The data confirmed that the inhibition of SARS-CoV-2 helicase by RBC was attributable to the displacement of $\mathrm{Zn}$ (II) in SARS-CoV-2 helicase by bismuth(III) ions.

\section{Discussion}

Historically, metal compounds have been used as antimicrobial agents. However, their utility for antiviral therapy has rarely been explored. In this study, we demonstrate the potential of metallodrugs and their related compounds for the treatment of COVID-19, providing a strategy for intervention in SAR-CoV-2 and possibly other viral infections. Wehaveidentified RBCas a potent anti-SAR-CoV-2 agent, both in vitro 
a

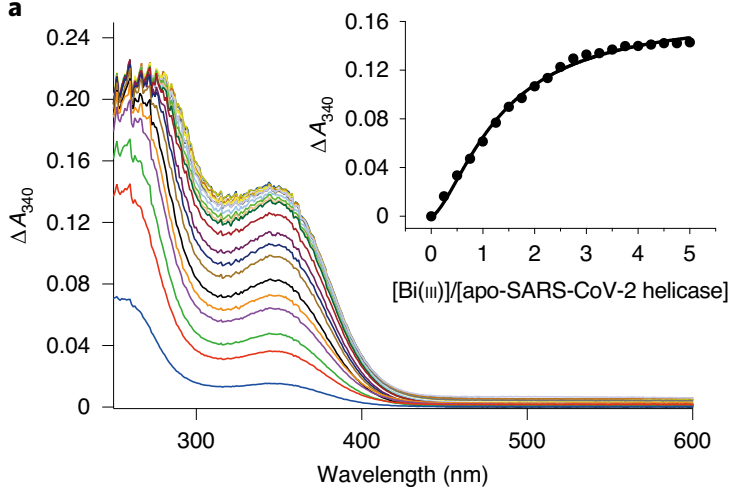

b

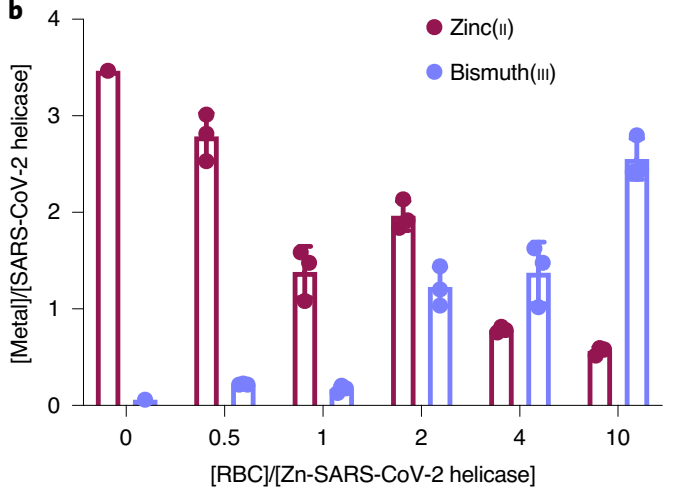

Fig. 5 | Displacement of essential zinc(II) in SARS-CoV-2 helicase with RBC. a, Difference UV-vis spectra for titration of various molar equivalents of bismuth(III) with apo-SARS-CoV-2 helicase. The inset shows a titration curve plotted at $\sim 340$ nm against the molar ratio of [bismuth(III)]/[apo-SARS-CoV-2 helicase]. The assays were performed twice and representative data are shown. $\mathbf{b}$, The substitution of zinc(II) in SARS-CoV-2 helicase by bismuth(II) over equilibrium dialysis. The metal contents of zinc(II) and bismuth(II) were determined by ICP-MS. The mean values of three replicates are shown and error bars indicate \pm s.d. In $\mathbf{a}$ and $\mathbf{b}$, measures of drug concentrations are based on metal content. All experiments were repeated twice for confirmation.

and in vivo, that targets the viral helicase (Figs. 1-5 and Extended Data Fig. 2). Compared with other bismuth(III) drug/compounds, the ranitidine moiety in $\mathrm{RBC}$ serves to stabilize the [Bi(citrate)] complex in aqueous solution ${ }^{23}$, thus leading to better anti-SARS-CoV-2 performance. Importantly, its potency in the established hamster model for COVID-19 is comparable to or even better than that of redemsivir, which has recently been approved by the United States for emergency use as COVID-19 treatment, despite its undetermined long-term side effects. RBC is a well-tolerated and efficacious anti-H. pylori and anti-ulcer drug ${ }^{40}$. Its extensively characterized safety profile may facilitate its immediate use in clinical trials in patients with COVID-19. The gastrointestinal tract is believed to be a potential transmission route and target organ of SARS-CoV-2 ${ }^{41}$, and $\mathrm{RBC}$ is known to maintain good pharmacological activity within the digestive tract environment. Our examination of RBC on colonic (Caco-2) cells demonstrated its potent activity to suppress SARS-CoV-2 replication (Fig. 1), which may support the use of RBC to restrict virus-induced gastrointestinal manifestations and potential faecal-oral transmission of COVID-19.

Increasing evidence, including our recent findings in a randomized trial, has suggested the advantage of combination therapy targeting multiple steps in the virus life cycle of SARS-CoV-2. Triple therapy consisting of interferon- $\beta 1 \mathrm{~b}$, lopinavir/ritonavir and ribavirin achieved significantly faster viral clearance and clinical improvement than monotherapy with lopinavir/ritonavir ${ }^{20}$. The multi-system manifestations of COVID-19 are caused by the combination of virus-induced cell damage and immunopathologies with dysregulated inflammatory responses. The dysregulated cytokine storm together with a compromised circulatory system leads to fulminant multi-organ dysfunction affecting lungs, heart, liver, kidneys, muscles, gastrointestinal tract and the neurological system ${ }^{42}$. Bismuth compounds are known to exhibit their antibacterial activities by disrupting multiple steps of the bacterial replication cycle ${ }^{43}$. In this study, we have shown that both the entry and post-entry steps of the SARS-CoV-2 replication cycle are targeted by RBC (Fig. 2h,i). We have used helicase as an illustrative example to demonstrate the in vitro interaction of RBC with a viral enzyme, that is, irreversibly disrupting enzyme function by the release of vital zinc(II) and possibly forming a non-functional metallodrug-bound enzyme in SARS-CoV-2-infected cells (Figs. 4 and 5). Further experiments should be conducted to investigate other antiviral mechanisms in addition to helicase inhibition. Given that key motifs (such as zinc-fingers) in viral enzymes are highly conserved, RBC may serve as a broad-spectrum inhibitor against coronavirus ${ }^{21}$. The high selectivity index and approved safety of RBC highlight the potential of this drug to be rapidly adopted for the treatment of COVID-19 disease after further clinical validation.

Although our overall results in this study were encouraging, several limitations were identified. First, the peak serum concentration of RBC achieved by standard oral dosing in humans $\left(C_{\max }, 33 \mathrm{ng} \mathrm{ml}^{-1}\right)$ is below its $\mathrm{EC}_{50}$ (equivalent to $480 \mathrm{ng} \mathrm{m}^{-1}$ ) against SARS-CoV-2 in non-human Vero E6 cells ${ }^{24}$. Nevertheless, intraperitoneal RBC treatment of our hamsters showed significantly better clinical, virological and histopathological outcomes, which might be due to the higher local drug concentration achieved in the hamster lungs. Our results indicate the need to better characterize the pharmacodynamics and pharmacokinetics of parenteral RBC and its related compounds in suitable animal models and humans to facilitate further analogue optimization and clinical use. The disparity may also be explained by the Vero E6 cells utilized for $\mathrm{EC}_{50}$ measurements; these do not express TMPRSS2, which is a major entry determinant of SARS-CoV- $2^{44}$. Apparently, higher inhibitory efficiency has been achieved by RBC in Calu- 3 cells (TMPRSS2 ${ }^{+}$) than that in Vero E6 cells (TMPRSS2-), indicating that RBC interferes with the TMPRSS2-primed virus entry $(P<0.01$, Extended Data Fig. 6). Second, in addition to affecting the viral helicase, bismuth(III) may also affect other zinc-containing viral proteins. We selected the viral helicase as an illustrative example in this study to demonstrate one of the drug's potential antiviral mechanisms in terms of zinc(II) displacement, because helicase is a conserved and potentially druggable target for SARS-CoV-2 and other human-pathogenic coronaviruses ${ }^{10}$. However, the raising of escape mutants is needed to confirm that SARS-CoV-2 helicase is one of the drug targets. Exploitation of proteomics and click chemistry may also be considered in future studies to facilitate the elucidation of RBC's multi-target in an unbiased manner. Third, additional RBC derivatives should be evaluated in an effort to enhance anti-SARS-CoV-2 potency and structure-activity analyses. Finally, combinatorial ('cocktail') regimens consisting of clinically approved drugs that are readily available and have exhibited anti-SARS-CoV-2 activity, such as the combination of $\mathrm{RBC}$, dexamethasone and interferon- $\beta 1 \mathrm{~b}$, should be evaluated in future studies.

\section{Methods}

Chemicals, virus and cell lines. Colloidal bismuth citrate (CBS) and RBC were kindly provided by Livzon Pharmaceutical Group. The RBC used in the current study possessed the composition ranitidine: $\mathrm{Bi}(\mathrm{III})$ :citrate $=1: 1: 1$ with the molecular formula $\mathrm{C}_{19} \mathrm{H}_{27} \mathrm{~N}_{4} \mathrm{O}_{10} \mathrm{SBi}^{23}$. $\mathrm{Bi}(\mathrm{TPP}), \mathrm{Bi}(\mathrm{TPyP})$ and $\mathrm{Bi}(\mathrm{NTA})$ were prepared as previously described ${ }^{45}$. Auranofin was purchased from MedChemExpress (MCE). Kanamycin sulfate and Luria-Bertani (LB) broth powder were purchased from 
Affymetrix. All other chemicals were purchased from Sigma-Aldrich unless otherwise stated and used directly without further purification. The SARS-CoV-2 (HKU-001a strain) was isolated from the nasopharyngeal aspirate specimen of a patient with laboratory-confirmed COVID-19 in Hong Kong ${ }^{46}$. Human colon epithelial (Caco-2) cells, African green monkey kidney (Vero E6) cells and human lung epithelial cells (Calu-3) were purchased from ATCC without further authentication and confirmed to be free of mycoplasma contamination by PlasmoTest (InvivoGen). HEK293-hACE2 stable cells were kindly provided by L. Liu (AIDS Institute, The University of Hong Kong). All cells were maintained in Dulbecco's modified Eagle medium (DMEM) supplemented with $10 \%$ heat-inactivated fetal bovine serum (FBS), $50 \mathrm{U} \mathrm{ml}^{-1}$ penicillin and $50 \mathrm{\mu g} \mathrm{ml}^{-1}$ streptomycin. SARS-CoV-2 pseudoviral particles (replication-deficient murine leukaemia virus (MLV) pseudotyped with the SARS-CoV-2 spike protein) were purchased from eEnzyme (cat no. SCV2-PsV-001). Cells were confirmed to be free of mycoplasma contamination by PlasmoTest (InvivoGen). All experiments with live viruses were conducted using Biosafety Level 3 facilities in Queen Mary Hospital, The University of Hong Kong, as previously described ${ }^{47}$.

Cell viability assay. A CellTiterGlo luminescent assay (Promega Corporation) was performed to detect the cytotoxicity of the selected compounds as previously described ${ }^{48}$. Briefly, Vero E6 cells $\left(4 \times 10^{4}\right.$ cells per well $)$ and Caco- 2 cells $\left(4 \times 10^{4}\right.$ cells per well) were incubated with different concentrations of the individual compound in 96-well plates for $48 \mathrm{~h}$, followed by the addition of the substrate and measurement of luminance 10 min later. Ridauta and $\mathrm{Au}\left(\mathrm{PEt}_{3}\right) \mathrm{Cl}$ were dissolved in DMSO, and the final percentage of DMSO was kept at $1 \%$ in culture medium. The $\mathrm{CC}_{50}$ values of the drug compounds were calculated by Sigma plot (SPSS) in an Excel add-in, ED50V10.

Plaque reduction assay. A plaque reduction assay was performed to plot the $50 \%$ antiviral effective dose $\left(\mathrm{EC}_{50}\right)$ of individual compounds, as we previously described but with slight modifications ${ }^{49}$. Briefly, Vero E6 cells were seeded at $4 \times 10^{5}$ cells per well in 12-well tissue culture plates on the day before carrying out the assay. After $24 \mathrm{~h}$ of incubation, 50 p.f.u. of SARS-CoV- 2 were added to the cell monolayer in the presence or absence of drug compounds and the plates were incubated further for $1 \mathrm{~h}$ at $37^{\circ} \mathrm{C}$ in $5 \% \mathrm{CO}_{2}$ before removal of unbound viral particles by aspiration of the medium and washing once with DMEM. Monolayers were then overlaid with DMEM containing $1 \%$ low-melting agarose (Cambrex Corporation) and appropriate concentrations of the individual compounds, inverted and then incubated as above for another $72 \mathrm{~h}$. The wells were fixed with $10 \%$ formaldehyde (BDH, Merck) overnight. After removal of the agarose plugs, the monolayers were stained with $0.7 \%$ crystal violet $(\mathrm{BDH}, \mathrm{Merck})$ and the plaques were counted. The percentage of plaque inhibition relative to the control wells (that is, without the addition of compound) was determined for each drug compound concentration. The $\mathrm{EC}_{50}$ values were calculated using Sigma plot (SPSS) in an Excel add-in, ED50V10. The selectivity index was calculated as the ratio of $\mathrm{CC}_{50}$ over $\mathrm{EC}_{50}$.

Viral load reduction assay. A viral load reduction assay was performed on Vero E6 and Caco- 2 cells, as described previously but with modifications ${ }^{50}$. Supernatant samples from the infected cells (MOI $=0.1$ ) were collected at 48 h.p.i. for qRT-PCR analysis of virus replication. Briefly, $100 \mu \mathrm{l}$ of viral supernatant was lysed with $400 \mu \mathrm{l}$ of AVL buffer and then extracted for total RNA with the QIAamp viral RNA mini kit (Qiagen). Real-time one-step qRT-PCR was used for quantitation of SARS-CoV-2 viral load using the QuantiNova Probe RT-PCR kit (Qiagen) with a LightCycler 480 Real-Time PCR System (Roche) as previously described ${ }^{2}$. Each 20 - $\mu$ l reaction mixture contained $10 \mu \mathrm{l}$ of $2 \times$ QuantiNova Probe RT-PCR Master Mix, $1.2 \mu \mathrm{l}$ of RNase-free water, $0.2 \mu \mathrm{l}$ of QuantiNova Probe RT-Mix, $1.6 \mu \mathrm{l}$ each of $10 \mu \mathrm{M}$ forward and reverse primer, $0.4 \mu \mathrm{l}$ of $10 \mu \mathrm{M}$ probe and $5 \mu \mathrm{l}$ of extracted RNA as the template. Reactions were incubated at $45^{\circ} \mathrm{C}$ for $10 \mathrm{~min}$ for reverse transcription, $95^{\circ} \mathrm{C}$ for 5 min for denaturation, followed by 45 cycles of $95^{\circ} \mathrm{C}$ for $5 \mathrm{~s}$ and $55^{\circ} \mathrm{C}$ for $30 \mathrm{~s}$. Signal detection was carried out and measurements were made in each cycle after the annealing step. The cycling profile ended with a cooling step at $40^{\circ} \mathrm{C}$ for $30 \mathrm{~s}$. The primers and probe sequences were against the RNA-dependent RNA polymerase/helicase (RdRP/Hel) gene region of SARS-Cov-2, as we previously described ${ }^{51}$.

Time-of-drug-addition assay. A time-of-drug-addition assay was performed to investigate which stage of the SARS-CoV-2 life cycle the compound affected. Briefly, Vero E6 cells were seeded in 24 -well plates $\left(2 \times 10^{5}\right.$ cells per well). The cells were infected with SARS-CoV-2 $(\mathrm{MOI}=2)$ and then incubated for $1 \mathrm{~h}$. The viral inoculum was then removed and the cells were washed twice with PBS. At 1 h.p.i. (that is, post-entry), the selected drugs, at an appropriate concentration, were added to the infected cells, followed by incubation at $37^{\circ} \mathrm{C}$ in $5 \% \mathrm{CO}_{2}$ until 9 h.p.i. (that is, one virus life cycle). For the time point of ' -2 to 0 h.p.i.' (that is, pre-incubation), drugs were added at $2 \mathrm{~h}$ before SARS-CoV-2 inoculation and removed at $0 \mathrm{~h}$, followed by virus inoculation as described above. For the time point ' $0-1$ h.p.i.' (that is, co-incubation), drugs were added together with the virus inoculation at 0 h.p.i., followed by drug removal at 1 h.p.i., then incubated in the fresh medium until 9 h.p.i. The group treated with drug during the full course of the infection was taken as a positive control, and the group treated with DMSO was included as a negative control, individually. At 9 h.p.i., the cell culture supernatant of each time point experiment was collected for viral yield measurements using qRT-PCR, as described above.

Immunofluorescence microscopy. Antigen expression in SARS-CoV-2-infected cells was detected with an in-house rabbit antiserum against SARS-CoV-2-N protein. Cell nuclei were labelled with the 4,6-diamidino-2-phenylindole (DAPI) nucleic acid stain from Thermo Fisher Scientific. The Alexa Fluor secondary antibodies were obtained from Thermo Fisher Scientific. Mounting was performed with the Diamond Prolong AntiFade mountant from Thermo Fisher Scientific.

Anti-SARS-CoV-2 evaluation of the selected compound in the golden Syrian hamster model. Male and female Syrian hamsters, aged 6-10 weeks, were kept in biosafety level housing and given access to standard pellet feed and water ad libitum, as previously described ${ }^{25}$. Hamsters were randomly allocated to experimental groups $(n=5)$ for antiviral evaluation. All experimental protocols were approved by the Animal Ethics Committee at the University of Hong Kong (CULATR) and were performed according to the standard operating procedures of the Biosafety Level 3 animal facilities (reference code CULATR 5370-20). The experiments were not blinded. Each hamster was intranasally inoculated with $10^{4}$ p.f.u. of SARS-CoV-2 in $100 \mu \mathrm{l}$ PBS under intraperitoneal ketamine (200 mg per kg body weight) and xylazine (10 mg per kg body weight) anaesthesia. At $6 \mathrm{~h}$ post virus challenge, hamsters were intraperitoneally given either RBC (150 mg per kg body weight per day) or remdesivir ( $15 \mathrm{mg}$ per kg body weight per day) or PBS (vehicle controls) for four consecutive days. Animals were monitored twice daily for clinical signs of disease. Their body weight and survival were monitored for 14 d.p.i. Five animals in each group were euthanized at 4 d.p.i. for virological and histolopathological analyses. Lung and nasal turbinate tissue samples were collected. Viral yield in the tissue homogenates was detected by TCID $_{50}$ and qRT-PCR methods. The cytokine and chemokine profiles of the hamster lungs were detected by the $2^{-\Delta \Delta C T}$ method using probe-based one-step qRT-PCR (Qiagen). Probe and primer sequences for each gene detection are listed in Extended Data Fig. 7.

The tissue pathology of infected animals was examined by $\mathrm{H} \& \mathrm{E}$ and immunofluorescence staining in accordance with an established protocol ${ }^{47}$. To differentiate lung pathology, semi-quantitative histology scores were given to lung tissue by grading the severity of damage in the bronchioles, alveoli and blood vessels and accumulating the total scores as follows. Bronchioles: 0, normal structure; 1 , mild peribronchiolar infiltration; 2, peribronchiolar infiltration plus epithelial cell death; 3 , score 2 and intra-bronchiolar wall infiltration and epithelium desquamation. Alveoli: 0, normal structure; 1 , alveolar wall thickening and congestion; 2 , focal alveolar space infiltration or exudation; 3 , diffuse alveolar space infiltration or exudation or haemorrhage. Blood vessel: 0 , normal structure; 1 , mild perivascular oedema or infiltration; 2 , vessel wall infiltration; 3 , severe endothelium infiltration.

\section{Gene cloning and construction of plasmid for SARS-CoV-2 helicase.}

SARS-CoV-2 helicase (that is, Nsp13) is one of the cleavage products (nonstructural proteins) of the viral polyprotein ORF1ab. The coding sequence of Nsp13 is within the range from 16237 to 18039 of the severe acute respiratory syndrome coronaviruses 2 isolate Wuhan-Hu-1, complete genome (NCBI GenBank accession no. NC_045512.2). There is neither a start nor stop codon. The DNA fragment of full-length Nsp13 was amplified from the viral cDNA using the primer pair of nCoV-Nsp13-F (BamHI): CGGGATCCATGGCTGTTGGGGCTTGTGTTCTT and nCoV-Nsp13-R (XhoI): CCGCTCGAGTCATTGTAAAGTTGCCACATTCCTAC by Phusion High-Fidelity DNA Polymerase (New England Biolabs) in a Veriti 96-well thermal cycler (Applied Biosystems). The cDNA was synthesized from viral RNA using a transcriptor first-strand cDNA synthesis kit (Roche) using random hexamer primers. The thermocycling conditions were $98^{\circ} \mathrm{C}$ for $30 \mathrm{~s}$ (initial denaturation), followed by $30 \mathrm{cycles}$ of amplification $\left(98^{\circ} \mathrm{C}\right.$ for $30 \mathrm{~s}, 62^{\circ} \mathrm{C}$ for $10 \mathrm{~s}$ and $72^{\circ} \mathrm{C}$ for $2 \mathrm{~min}$ ). The PCR product was digested by BamHI and XhoI, and then inserted into the plasmid pET28-a(+) using T4 DNA ligase, generating pET28-Nsp13, which produces $\mathrm{His}_{6}-$ and $\mathrm{T} 7$-tagged helicase. The ligation product was transformed into E. coli $\mathrm{DH} 10 \mathrm{~B}$ before sequencing validation. The validated plasmid pET28-Nsp13 was then transformed into E. coli BL21(DE3).

Overexpression and purification of SARS-CoV-2 helicase. E. coli BL21(DE3) harbouring pET28-Nsp13 was cultured in LB medium overnight at $37^{\circ} \mathrm{C}$ with supplementation of $50 \mu \mathrm{g} \mathrm{ml}^{-1} \mathrm{kanamycin}$. The culture was then amplified with a 1:100 dilution factor in 11 of LB medium until an optical density at $600 \mathrm{~nm}$ of 0.6 was reached. Overexpression of the helicase was induced by $200 \mathrm{mM}$ isopropyl $\beta$-D-1-thiogalactopyranoside (IPTG) at $25^{\circ} \mathrm{C}$ for $16 \mathrm{~h}$ with agitation at 200 r.p.m. After overexpression, the bacterial pellet was collected by centrifugation at $5,000 \mathrm{~g}, 4^{\circ} \mathrm{C}$ for $10 \mathrm{~min}$ and washed once with binding buffer A $(20 \mathrm{mM}$ Tris- $\mathrm{HCl}$, $\mathrm{pH} 6.8,500 \mathrm{mM} \mathrm{NaCl}, 20 \mathrm{mM}$ imidazole). The pellet was resuspended in buffer A supplemented with $0.1 \%$ Triton X-100 and cOmplete Protease Inhibitor Cocktail (Roche) and lysed by sonication. The bacterial lysate was centrifuged at $13,000 \mathrm{~g}$ at $4^{\circ} \mathrm{C}$ for $30 \mathrm{~min}$. The supernatant was loaded onto a buffer A-balanced 
5-ml Ni(II)-charged HiTrap chelating column (GE Life Sciences), which was then washed with buffer $\mathrm{A}$. The recombinant protein was eluted with the linear gradient of elution buffer B (buffer A with $250 \mathrm{mM}$ imidazole). The collected fractions of eluent were checked using SDS-PAGE, then the purest fractions were pooled together and subjected to thrombin digestion of $\mathrm{His}_{6}$-tag. The digested protein solution was loaded onto the 5-ml HiTrap chelating HP column to remove $\mathrm{His}_{6}$-tag and undigested protein. The product was further purified by gel filtration using a HiLoad 16/600 Superdex 200 prep grade column (GE Life Sciences) with gel-filtration buffer C (20 mM Tris- $\mathrm{HCl}, \mathrm{pH} 6.8,250 \mathrm{mM} \mathrm{NaCl})$. An ÄKTA FPLC system (GE Life Sciences) was used for protein purification. An image of the purified protein is shown in Extended Data Fig. 4 and an uncropped image in Source Data Extended Data Fig. 4.

ATPase assay. ATPase assays were performed by measuring the release of phosphate based on a modified method (previously described ${ }^{21}$ ) using an ATPase assay kit (ab234055, Abcam). In a volume of $48 \mu$, typically $2 \mathrm{nM}$ protein was incubated with varying concentrations of metal drug/compounds in ATPase reaction buffer $(20 \mathrm{mM}$ Tris- $\mathrm{HCl}, \mathrm{pH} 6.8,5 \mathrm{mM} \mathrm{MgCl}, 2 \mathrm{mM}$ tris(2-carboxyethyl)phosphine (TCEP)) for

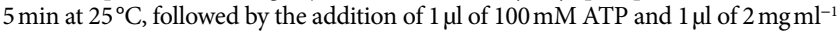
$\operatorname{poly}(\mathrm{U})$ to initiate the reaction. All drugs/compounds were dissolved in DMSO, and the final percentage of DMSO was kept at $2 \%$ in the reaction solution. Enzyme treated with $2 \%$ DMSO served as a negative control. About $15 \mu \mathrm{l}$ of the reaction developer was added to each well and the colour developed for $15 \mathrm{~min}$. The mixtures were subsequently subjected to absorbance measurements at $650 \mathrm{~nm}$ using a SpectraMax iD3 Multi-Mode microplate reader. The relative ATPase activity was the ratio between the activity of the samples in the presence of metal drug/compounds and the activity of the control sample, and is therefore expressed as a percentage. The assays were performed in triplicate and repeated on different days.

FRET-based DNA duplex unwinding assays. FRET-based assays were performed based on a previously described method, with modifications ${ }^{21}$. DNA oligomers were synthesized and purified by high-performance liquid chromatography: FL-Cy3 oligo (5'-TTTTTTTTTTTTTTTT TTTTCGAGCACCGCTGCGGCTGCACC(Cy3)-3'), RL-BHQ oligo (5'-(BHQ2)GGTGCAGCCGCAGCGGTGCTCG-3') and RL oligo (5'-GGTGCAGCCGCAGCGGTGCTCG-3') (Metabion). The two oligomers were mixed in a ratio of FL-Cy3:RL-BHQ of $1: 1.5$ at final concentrations of $10 \mu \mathrm{M}$ and $15 \mu \mathrm{M}$, respectively, in annealing buffer $(20 \mathrm{mM}$ Tris- $\mathrm{HCl}, \mathrm{pH} 8.0,150 \mathrm{mM} \mathrm{NaCl})$. They were annealed by heating to $90^{\circ} \mathrm{C}$ for $2 \mathrm{~min}$ in a thermocycler ( $\mathrm{S} 1000$ thermal cycler, Bio-Rad), then cooled slowly to $25^{\circ} \mathrm{C}$ at a rate of $\sim 1^{\circ} \mathrm{C} \mathrm{min}{ }^{-1}$. The FRET assay was performed by incubating $10 \mathrm{nM}$ protein with varying concentrations of RBC in $48.5 \mu \mathrm{l}$ of helicase reaction mix $(20 \mathrm{mM}$ Tris- $\mathrm{HCl}$ buffer, $\mathrm{pH} 7.4,150 \mathrm{mM}$ $\mathrm{NaCl}, 0.1 \mathrm{mg} \mathrm{ml}^{-1} \mathrm{BSA}, 5 \mathrm{mM} \mathrm{MgCl}, 5 \mathrm{mM}$ TCEP, $5 \%$ glycerol) in a 96-well black polystyrene microplate (Corning) at $25^{\circ} \mathrm{C}$, then $0.5 \mu \mathrm{l}$ of $100 \mathrm{mM}$ ATP and $1.5 \mu \mathrm{l}$ of oligo mixture were added to achieve final concentrations of FL-Cy3:RL-BHQ oligo and RL oligo of $5 \mathrm{nM}$ and $10 \mathrm{nM}$, respectively. Reactions were incubated for $2 \mathrm{~min}$, then the change in fluorescence $\left(\lambda_{\mathrm{ex}}=550 \mathrm{~nm}, \lambda_{\mathrm{em}}=620 \mathrm{~nm}\right)$ was measured using a SpectraMax iD3 multimode microplate reader to determine the extent of DNA-duplex unwinding. All the drugs/compounds were dissolved in DMSO, and the final percentage of DMSO was kept at $2 \%$ in the reaction solutions. Enzyme treated with 2\% DMSO served as the negative control. The relative DNA unwinding activity is the ratio between the activity of the samples in the presence of RBC and the activity of the control sample, and is therefore expressed as a percentage. The assays were performed in triplicate and repeated on different days

Michaelis-Menten kinetics. For ATPase assays, SARS-CoV-2 helicase (0.5 nM) was incubated with $\mathrm{RBC}(0,0.01,0.05,0.1$ and $0.5 \mu \mathrm{M})$ in ATPase reaction mixture in a total volume of $50 \mu \mathrm{l}$ at $25^{\circ} \mathrm{C}$ for $30 \mathrm{~min}$. To each aliquot of reaction mix we added $30 \mu \mathrm{l}$ of the reaction developer and then ATP as substrate to achieve final concentrations of $0.2,0.5,1,2,4,6$ and $8 \mathrm{mM}$. The control experiment was performed in the absence of inhibitors under the same conditions. The values of $V_{m x}, K_{\mathrm{m}}$ and $K_{\mathrm{i}}$ for both uninhibited and inhibited reactions were obtained by fitting the data into the double reciprocal Lineweaver-Burk plots. For DNA unwinding assays, SARS-CoV-2 helicase $(10 \mathrm{nM})$ was incubated with RBC $(0,0.1$, 0.2 and $0.5 \mu \mathrm{M})$ in helicase reaction mix at $25^{\circ} \mathrm{C}$ for $5 \mathrm{~min}$. FL-Cy3:RL-BHQ oligo and RL oligo were added to the enzyme to achieve final substrate concentrations of $2.5,5,7.5,10,15$ and $20 \mathrm{nM}$, respectively. The control experiment was performed in the absence of inhibitors under the same conditions. The values of $V_{\max }, K_{\mathrm{m}}$ and $K_{\mathrm{i}}$ for both uninhibited and inhibited reactions were obtained by fitting the data into the double reciprocal Lineweaver-Burk plots.

Zinc supplementation assay. Apo-SARS-CoV-2 helicase $(10 \mu \mathrm{M})$ was first prepared by dialysis in zinc(II) chelating buffer $(20 \mathrm{mM}$ Tris- $\mathrm{HCl}, \mathrm{pH} 8.0,150 \mathrm{mM}$ $\mathrm{NaCl}, 0.5 \mathrm{mM}$ EDTA, $2 \mathrm{mM}$ TCEP). Bismuth-bound SARS-CoV-2 helicase was then prepared by dialysing apo-proteins with excess amounts of bismuth(III) nitrate in glycerol dialysis buffer $(50 \mathrm{mM}$ Tris- $\mathrm{HCl}, \mathrm{pH} 7.4,20 \mathrm{mM} \mathrm{NaCl}$, $5 \mathrm{mM}$ TCEP, $20 \%$ glycerol) at $4{ }^{\circ} \mathrm{C}$ overnight, followed by removal of unbound bismuth(III) and verification of the bound bismuth(III) by ICP-MS. The resulting protein was mixed with $\mathrm{ZnSO}_{4}$ at concentrations up to 50 molar equivalents for
SARS-CoV-2 and incubated for $2 \mathrm{~h}$ at room temperature and then subjected for the ATPase and DNA unwinding assays as mentioned above.

UV-vis spectroscopy. UV-vis spectroscopic titration was carried out on a Varian Cary 50 spectrophotometer at a rate of $360 \mathrm{~nm} \mathrm{~min}^{-1}$ using a $1-\mathrm{cm}$ quartz cuvette at $25^{\circ} \mathrm{C}$. Aliquots of $2 \mathrm{mM} \mathrm{Bi}(\mathrm{NTA})$ stock solution were stepwise titrated into apo-SARS-CoV-2 helicase $(10 \mu \mathrm{M})$ in titration buffer $(50 \mathrm{mM}$ Tris- $\mathrm{HCl}, \mathrm{pH} 7.4$, $20 \mathrm{mM} \mathrm{NaCl}, 2 \mathrm{mM}$ TCEP) and UV-vis spectra were recorded in a range of 250 $600 \mathrm{~nm} 10 \mathrm{~min}$ after each addition. The binding of bismuth(III) to the protein was monitored by the increase in absorption at $\sim 340 \mathrm{~nm}$. The ultraviolet titration curve was fitted with the Ryan-Weber nonlinear equation and $K_{d}$ was estimated.

Zinc displacement analysis. SARS-CoV-2 helicase $(3 \mu \mathrm{M})$ was incubated with $10 \mu \mathrm{M} \mathrm{ZnSO}_{4}$ in dialysis buffer $(20 \mathrm{mM}$ Tris- $\mathrm{HCl}, \mathrm{pH} 7.4,150 \mathrm{mM} \mathrm{NaCl}, 5 \mathrm{mM}$ TCEP) overnight at $4{ }^{\circ} \mathrm{C}$, and the unbound $\mathrm{Zn}$ (II) ions were removed by dialysis in $\mathrm{Zn}$-free dialysis buffer to ensure that $\mathrm{Zn}$ (II) was fully loaded into the proteins. The resulting protein was then incubated with various concentrations of RBC by dialysis at $4{ }^{\circ} \mathrm{C}$ overnight with mild shaking. The samples were subsequently dialysed in the dialysis buffer to remove unbound metal ions, and then acidified by concentrated nitric acid at $60^{\circ} \mathrm{C}$ for $2 \mathrm{~h}$. Samples were diluted to a detectable concentration range and subjected to ICP-MS analysis (Agilent 7700x, Agilent Technologies) with ${ }^{115} \mathrm{In}$ as an internal standard for ${ }^{209} \mathrm{Bi}$, ${ }^{66} \mathrm{Zn}$. Protein concentrations were quantified by standard bicinchoninic acid assay (Thermal Fisher Scientific).

Statistical analysis. All statistical analyses were performed on three independent experiments, or more if otherwise stated, using Prism 8.0 (GraphPad Software Inc.) software.

Reporting Summary. Further information on research design is available in the Nature Research Reporting Summary linked to this Article.

\section{Data availability}

Data that support the findings of this study are available from the corresponding author upon reasonable request. Source data are provided with this paper.

Received: 26 June 2020; Accepted: 21 September 2020; Published online: 7 October 2020

\section{References}

1. Zhou, P. et al. A pneumonia outbreak associated with a new coronavirus of probable bat origin. Nature 579, 270-273 (2020).

2. Chan, J. F.-W. et al. A familial cluster of pneumonia associated with the 2019 novel coronavirus indicating person-to-person transmission: a study of a family cluster. Lancet 395, 514-523 (2020).

3. WHO Coronavirus Disease (COVID-19) Situation Report, 157 (World Health Organization, 2002)

4. Stadler, K. et al. SARS-beginning to understand a new virus. Nat. Rev. Microbiol. 1, 209-218 (2003)

5. Chan, J. F. W. et al. Middle East respiratory syndrome coronavirus: another zoonotic betacoronavirus causing SARS-like disease. Clin. Microbiol. Rev. 28, 465-522 (2015)

6. Wrapp, D. et al. Cryo-EM structure of the 2019-nCoV spike in the prefusion conformation. Science 367, 1260-1263 (2020).

7. Lan, J. et al. Structure of the SARS-CoV-2 spike receptor-binding domain bound to the ACE2 receptor. Nature 581, 215-220 (2020).

8. Shang, J. et al. Structural basis of receptor recognition by SARS-CoV-2 Nature 581, 221-224 (2020)

9. Sheahan, T. P. et al. An orally bioavailable broad-spectrum antiviral inhibits SARS-CoV-2 in human airway epithelial cell cultures and multiple coronaviruses in mice. Sci. Transl. Med. 12, eabb5883 (2020).

10. Zumla, A., Chan, J. F. W., Azhar, E. I., Hui, D. S. C. \& Yuen, K.-Y. Coronaviruses-drug discovery and therapeutic options. Nat. Rev. Drug Discov. 15, 327-347 (2016).

11. Zhang, L. et al. Crystal structure of SARS-CoV-2 main protease provides a basis for design of improved alpha-ketoamide inhibitors. Science 368, 409-412 (2020).

12. Jin, Z. et al. Structure of M(pro) from COVID-19 virus and discovery of its inhibitors. Nature 582, 289-293 (2020).

13. Gao, Y. et al. Structure of the RNA-dependent RNA polymerase from COVID-19 virus. Science 368, 779-782 (2020).

14. Sanders, J. M., Monogue, M. L., Jodlowski, T. Z. \& Cutrell, J. B. Pharmacologic treatments for coronavirus disease 2019 (COVID-19): a review. JAMA 323, 1824-1836 (2020).

15. Serafin, M. B. et al. Drug repositioning an alternative for the treatment of coronavirus COVID-19. Int. J. Antimicrob. Agents 55, 105969 (2020).

16. Munster, V. J. et al. Respiratory disease and virus shedding in rhesus macaques inoculated with SARS-CoV-2. Nature 585, 268-272 (2020). 
17. NIH Clinical Trial Shows Remdesivir Accelerates Recovery from Advanced COVID-19. National Institutes of Health https://www.nih.gov/news-events/ news-releases/nih-clinical-trial-shows-remdesivir-accelerates-recoveryadvanced-covid-19 (2020).

18. Wang, Y. et al. Remdesivir in adults with severe COVID-19: a randomised, double-blind, placebo-controlled, multicentre trial. Lancet 395 , 1569-1578 (2020).

19. The RECOVERY Collaborative Group. Dexamethasone in hospitalized patients with Covid-19-preliminary report. New Engl. J. Med. https://doi. org/10.1056/NEJMoa2021436 (2020).

20. Hung, I. F.-N. et al. Triple combination of interferon beta-1b, lopinavir-ritonavir, and ribavirin in the treatment of patients admitted to hospital with COVID-19: an open-label, randomised, phase 2 trial. Lancet 395, 1695-1704 (2020).

21. Yang, N. et al. Bismuth complexes inhibit the SARS coronavirus. Angew. Chem. Int. Ed. 46, 6464-6468 (2007).

22. Pipkin, G. A., Mills, J. G., Kler, L., Dixon, J. S. \& Wood, J. R. The safety of ranitidine bismuth citrate in controlled clinical studies. Pharmacoepidem. Drug Safe. 5, 399-407 (1996).

23. Sadler, P. J. \& Sun, H. Ranitidine bismuth(III) citrate. J. Chem. Soc. Dalton Trans. https://doi.org/10.1039/DT9950001395 (1995).

24. Koch, K. M., Davis, I. M., Gooding, A. E. \& Yin, Y. Pharmacokinetics of bismuth and ranitidine following single doses of ranitidine bismuth citrate. Br. J. Clin. Pharmacol. 42, 201-205 (1996).

25. Chan, J. F.-W. et al. Simulation of the clinical and pathological manifestations of coronavirus disease 2019 (COVID-19) in golden Syrian hamster model: implications for disease pathogenesis and transmissibility. Clin. Infect. Dis. https://doi.org/10.1093/cid/ciaa325 (2020).

26. Wang, $M$. et al. Remdesivir and chloroquine effectively inhibit the recently emerged novel coronavirus (2019-nCoV) in vitro. Cell Res. 30, 269-271 (2020).

27. Tay, M. Z., Poh, C. M., Rénia, L., MacAry, P. A. \& Ng, L. F. P. The trinity of COVID-19: immunity, inflammation and intervention. Nat. Rev. Immunol. 20, 363-374 (2020).

28. Huang, C. et al. Clinical features of patients infected with 2019 novel coronavirus in Wuhan, China. Lancet 395, 497-506 (2020).

29. Cheng, T. et al. Bismuth drugs tackle Porphyromonas gingivalis and attune cytokine response in human cells. Metallomics 11, 1207-1218 (2019).

30. Wang, R. et al. Bismuth antimicrobial drugs serve as broad-spectrum metallo- $\beta$-lactamase inhibitors. Nat. Commun. 9, 439 (2018).

31. Cun, S. J. \& Sun, H. A zinc-binding site by negative selection induces metallodrug susceptibility in an essential chaperonin. Proc. Natl Acad. Sci. USA 107, 4943-4948 (2010).

32. Baez-Santos, Y. M., St John, S. E. \& Mesecar, A. D. The SARS-coronavirus papain-like protease: structure, function and inhibition by designed antiviral compounds. Antiviral Res. 115, 21-38 (2015).

33. Jia, Z. H. et al. Delicate structural coordination of the severe acute respiratory syndrome coronavirus Nsp13 upon ATP hydrolysis. Nucleic Acids Res. 47, 6538-6550 (2019).

34. Patel, S. S. \& Donmez, I. Mechanisms of helicases. J. Biol. Chem. 281, 18265-18268 (2006).

35. Keum, Y.-S. \& Jeong, Y.-J. Development of chemical inhibitors of the SARS coronavirus: viral helicase as a potential target. Biochem. Pharmacol. 84, 1351-1358 (2012).

36. Caruthers, J. M. \& McKay, D. B. Helicase structure and mechanism. Curr Opin. Struct. Biol. 12, 123-133 (2002).

37. Mirza, M. U. \& Froeyen, M. Structural elucidation of SARS-CoV-2 vital proteins: computational methods reveal potential drug candidates against main protease, Nsp12 polymerase and Nsp13 helicase. J. Pharm. Anal. 10 320-328 (2020).

38. Tanner, J. A. et al. The severe acute respiratory syndrome (SARS) coronavirus NTPase/helicase belongs to a distinct class of $5^{\prime}$ to $3^{\prime}$ viral helicases. J. Biol. Chem. 278, 39578-39582 (2003)

39. Adedeji, A. O. et al. Severe acute respiratory syndrome coronavirus replication inhibitor that interferes with the nucleic acid unwinding of the viral helicase. Antimicrob. Agents Chemother. 56, 4718-4728 (2012).

40. Bardhan, K. D., Dallaire, C., Eisold, H. \& Duggan, A. E. Ranitidine bismuth citrate with clarithromycin for the treatment of duodenal ulcer. Gut 41, 181-186 (1997).

41. Lin, L. et al. Gastrointestinal symptoms of 95 cases with SARS-CoV-2 infection. Gut 69, 997-1001 (2020).

42. Roberts, $M$. et al. Covid-19: a complex multisystem clinical syndrome. The BMJ Opinion https://blogs.bmj.com/bmj/2020/05/01/covid-19 a-complex-multisystem-clinical-syndrome/ (2020).
43. Li, H. \& Sun, H. Recent advances in bioinorganic chemistry of bismuth. Curr. Opin. Chem. Biol. 16, 74-83 (2012).

44. Hoffmann, M. et al. SARS-CoV-2 cell entry depends on ACE2 and TMPRSS2 and is blocked by a clinically proven protease inhibitor. Cell 181, 271-280 (2020).

45. Wang, R. et al. Bismuth porphyrin antagonizes cisplatin-induced nephrotoxicity via unexpected metallothionein-independent mechanisms. iScience 23, 101054 (2020).

46. Chu, H. et al. Comparative tropism, replication kinetics, and cell damage profiling of SARS-CoV-2 and SARS-CoV with implications for clinical manifestations, transmissibility and laboratory studies of COVID-19: an observational study. Lancet Microbe 1, e14-e23 (2020).

47. Yuan, S. et al. SREBP-dependent lipidomic reprogramming as a broad-spectrum antiviral target. Nat. Commun. 10, 120 (2019)

48. Yuan, S. et al. A novel small-molecule compound disrupts influenza A virus PB2 cap-binding and inhibits viral replication. J. Antimicrob. Chem. 71, 2489-2497 (2016).

49. Chan, J. F.-W. et al. The celecoxib derivative kinase inhibitor AR-12 (OSU-03012) inhibits Zika virus via down-regulation of the PI3K/Akt pathway and protects Zika virus-infected A129 mice: a host-targeting treatment strategy. Antiviral Res. 160, 38-47 (2018).

50. Yuan, S. et al. Cross-protection of influenza A virus infection by a DNA aptamer targeting the PA endonuclease domain. Antimicrob. Agents Chemother. 59, 4082-4093 (2015).

51. Chan, J. F.-W. et al. Improved molecular diagnosis of COVID-19 by the novel, highly sensitive and specific COVID-19-RdRp/Hel real-time reverse transcription-PCR assay validated in vitro and with clinical specimens. J. Clin. Microb. 58, e00310-e00320 (2020).

\section{Acknowledgements}

This study was partly supported by funding from the Research Impact Fund (R707018) of the Research Grants Council (RGC), HKSAR of China and the National Key R\&D Programmes of China (grant nos. 2020YFA0707500 and 2020YFA0707504), the University of Hong Kong (HKU) Seed Fund for Basic Research (no. 201909185060) and donations from the Lo Ying Shek Chi Wai Foundation, Richard Yu and Carol Yu, the Shaw Foundation of Hong Kong, Michael Seak-Kan Tong, May Tam Mak Mei Yin, Hong Kong Sanatorium \& Hospital, Hui Ming, Hui Hoy and Chow Sin Lan Charity Fund Limited, Chan Yin Chuen Memorial Charitable Foundation, Marina Man-Wai Lee the Hong Kong Hainan Commercial Association South China Microbiology Research Fund, the Jessie \& George Ho Charitable Foundation, Perfect Shape Medical Limited, Kai Chong Tong, Foo Oi Foundation Limited, Tse Kam Ming Laurence, and Norman \& Cecilia Yip Foundation. The funding sources had no role in the study design, data collection, analysis, interpretation or writing of the paper.

\section{Author contributions}

S.Y., K.K.-H.C. and Z.-W.Y. performed the antiviral evaluation in cell cultures. R.W., S.Y., J.F.-W.C., T.C. and S.W. generated biochemical reagents and performed all enzyme activity assays. R.W. and H.L. performed the ultraviolet titrations and displacement assays. R.W. synthesized and prepared the tested compounds/drugs. S.Y. and J.F.-W.C. performed the animal experiments. A.J.Z. and A.C.-Y.L. conducted the histopathological analysis. S.Y. R.W., J.F.-W.C., L.J. and H.L. analysed data. H.S. and K.-Y.Y. supervised the study and design of the experiments. H.S., K.-Y.Y., S.Y., R.W., D.-Y.J. and H.L. wrote the manuscript.

\section{Competing interests}

H.S., K.-Y.Y., S.Y., R.W., H.L., J.F.-W.C., T.C. and S.W. have a pending patent application related to this manuscript. J.F.-W.C. has received travel grants from Pfizer Corporation Hong Kong and Astellas Pharma Hong Kong Corporation Limited, and was an invited speaker for Gilead Sciences Hong Kong Limited and Luminex Corporation. The other authors declare no competing interests.

\section{Additional information}

Extended data is available for this paper at https:/doi.org/10.1038/s41564-020-00802-x. Supplementary information is available for this paper at https://doi.org/10.1038/ s41564-020-00802-x.

Correspondence and requests for materials should be addressed to K.-Y.Y. or H.S. Peer review information Peer reviewer reports are available.

Reprints and permissions information is available at www.nature.com/reprints. Publisher's note Springer Nature remains neutral with regard to jurisdictional claims in published maps and institutional affiliations.

(c) The Author(s), under exclusive licence to Springer Nature Limited 2020 


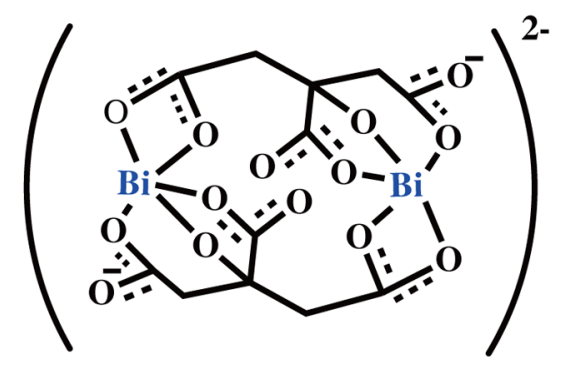

CBS

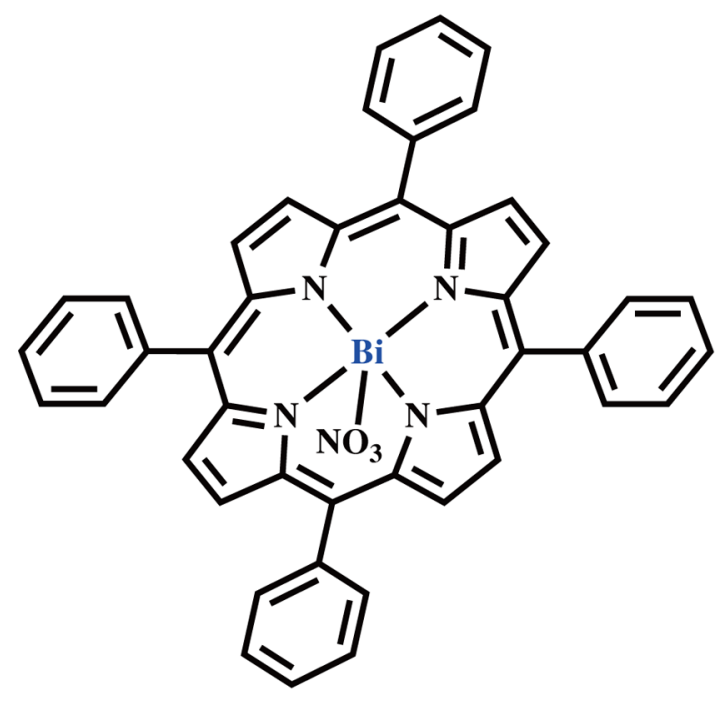

Bi(TPP)<smiles>CCP(CC)(CC)(CC)[Al]SC1OC(COC(C)=O)C(OC(C)=O)C(OC(C)=O)C1OC(C)=O</smiles>

\section{Auranofin}
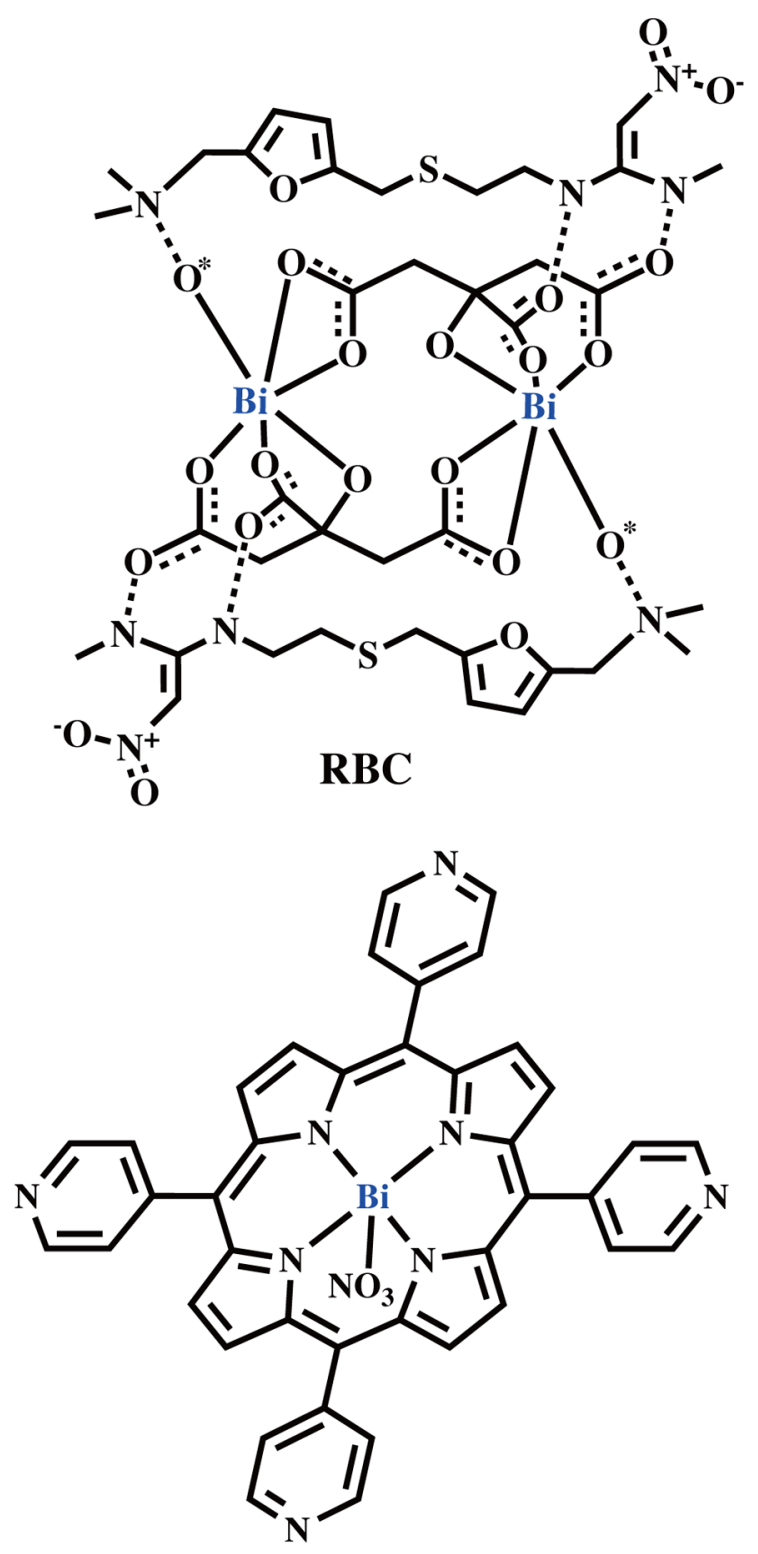

Bi(TPyP)<smiles>CC[PH](CC)(CC)[Al]Cl</smiles>

\section{$\mathbf{A u}\left(\mathbf{P E t}_{\mathbf{3}}\right) \mathrm{Cl}$}

Extended Data Fig. 1 | Chemical structures of selected metal drug/compounds. The dimeric units of both CBS and RBC are shown. Note that the asterisk in structure of RBC represents those oxygens from adjacent citrate molecules, which have at least one hydrogen bond to nitrogen from neighboring ranitidine molecules ${ }^{42}$. 


\begin{tabular}{|c|c|c|c|c|}
\hline \multirow{2}{*}{ Compound* } & \multicolumn{2}{|c|}{$\mathrm{CC}_{50}( \pm \mathrm{SD})(\mu \mathrm{M})$} & \multirow{2}{*}{$\frac{\mathbf{E C}_{50}( \pm \mathbf{S D})(\mu \mathrm{M})}{\text { Vero E6 }}$} & \multirow{2}{*}{$\begin{array}{c}\text { Selectivity index } \\
\text { Vero E6 } \\
\end{array}$} \\
\hline & Vero E6 & Caco2 & & \\
\hline CBS & $3254 \pm 21$ & $3740 \pm 125$ & $4.6 \pm 0.4$ & 707 \\
\hline $\mathrm{RBC}$ & $2243 \pm 43$ & $2486 \pm 65$ & $2.3 \pm 0.5$ & 975 \\
\hline Bi(TPP) & $>400^{\#}$ & $>400$ & $3.9 \pm 1.2$ & $>103$ \\
\hline Bi(ТРyP) & $>400$ & $>400$ & $7.5 \pm 0.9$ & $>53$ \\
\hline Auranofin & $14.2 \pm 1.3$ & N.D $\&$ & N.D & N.D \\
\hline $\mathrm{Au}\left(\mathrm{PEt}_{3}\right) \mathrm{Cl}$ & $13.5 \pm 1.8$ & N.D & N.D & N.D \\
\hline
\end{tabular}

* The measure of drug concentrations was based on metal content.

\# indicates the maximal soluble concentration used in the study.

\& N.D: not determined.

Extended Data Fig. 2 | Cytotoxicity and antiviral activity of the selected compounds. Summary of $\mathrm{CC}_{50}$ and $\mathrm{EC}_{50}$ of the selected compounds. 


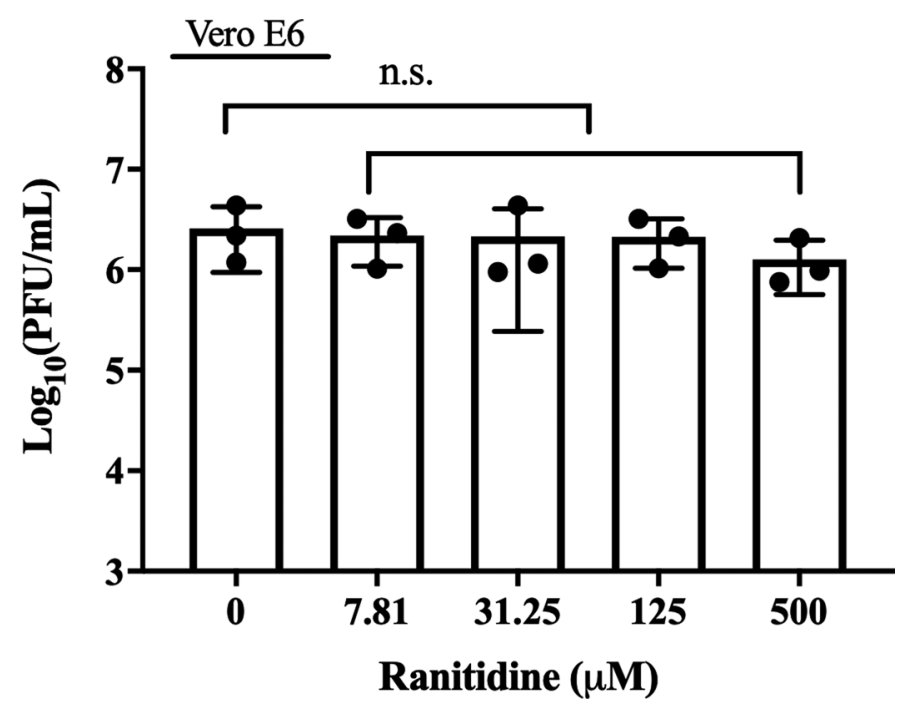

Extended Data Fig. 3 | Live virus particle in the cell culture supernatant after the treatment of SARS-CoV-2-infected Vero E6 cells (0.1 MOI, 48 hpi) with ranitidine. One-way ANOVA was used to compare the treatment groups with the negative control group $(0 \mu \mathrm{M}$, that is $0.1 \% \mathrm{DMSO})$. The results are shown as mean \pm S.D. of $n=3$ biologically independent samples. Statistical significance was calculated using an unpaired two-tailed Student's t-test, n.s. indicates non-significant. 
$\mathbf{a}$

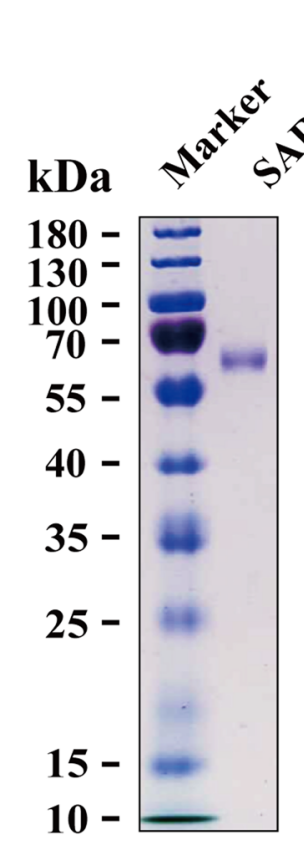

b

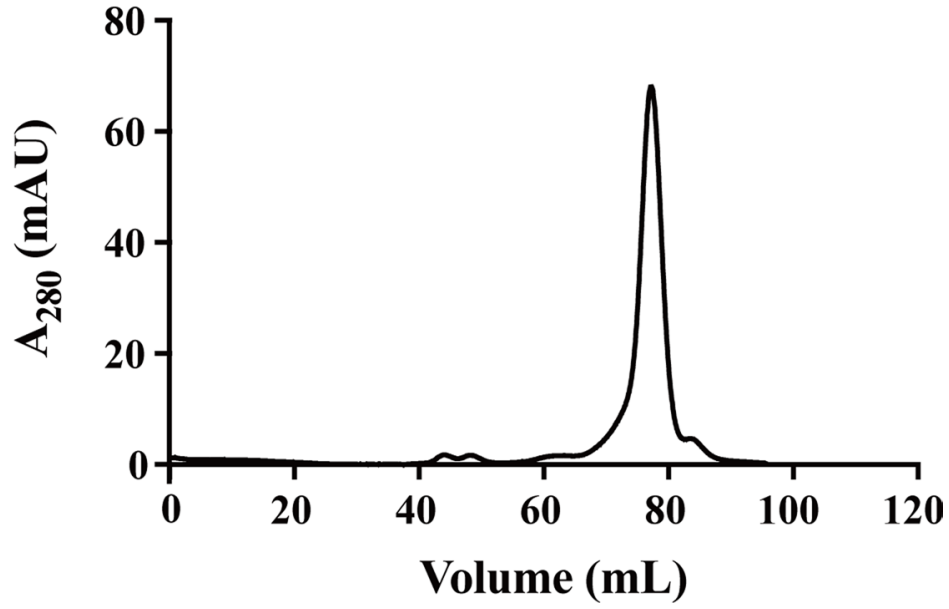

Extended Data Fig. 4 | The purification of SARS-CoV-2 helicase. a, The SDS-PAGE gel of SARS-CoV-2 helicase. The left lane: marker; the right lane: SARS-CoC-2 Nsp-13 (helicase) b, Size-exclusion chromatography profile of SARS-CoV-2 helicase. The uncropped scan of gel was shown in Supplementary Fig. 1. 


\begin{tabular}{ccc}
\hline & \multicolumn{2}{c}{ IC $_{\mathbf{5 0}}( \pm \mathbf{S D})(\mu \mathrm{M})$} \\
\cline { 2 - 3 } Compound $^{*}$ & ATPase activity & $\begin{array}{c}\text { dsDNA-unwinding } \\
\text { activity }\end{array}$ \\
\hline CBS & $1.88 \pm 0.12$ & $1.24 \pm 0.02$ \\
RBC & $0.69 \pm 0.12$ & $0.70 \pm 0.13$ \\
Bi(TPP) & $2.39 \pm 0.02$ & $3.69 \pm 0.26$ \\
Bi(TPyP) & $4.68 \pm 1.39$ & $2.64 \pm 0.16$ \\
Auranofin & $1.20 \pm 0.02$ & $0.57 \pm 0.03$ \\
Au(PEt $\left.{ }_{3}\right) C 1$ & $0.23 \pm 0.01$ & $0.34 \pm 0.07$ \\
\hline
\end{tabular}

* The measure of drug concentrations was based on metal content.

Extended Data Fig. 5 | Inhibitory potency of the selected compounds on SARS-CoV-2 helicase. Summary of IC ${ }_{50}$ of the selected compounds towards ATPase and DNA-unwinding activity of SARS-CoV-2 helicase. 
- Vehicle $\nabla$ Pylorid

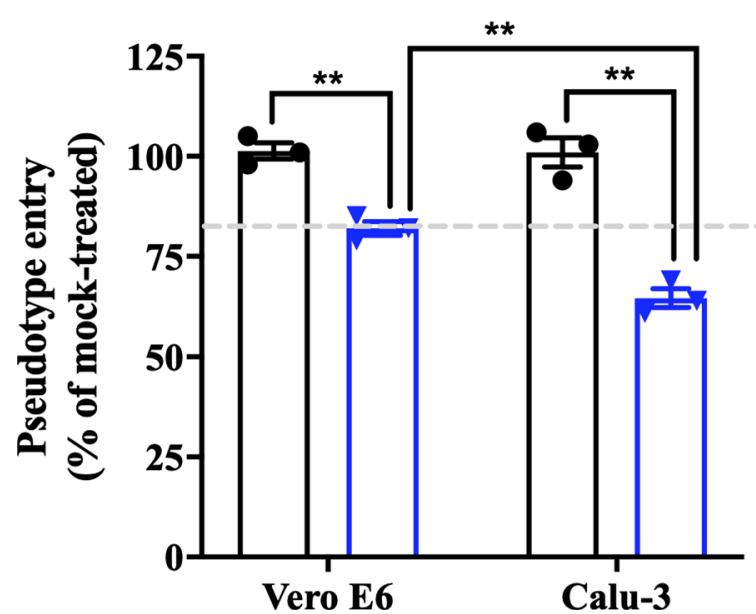

Extended Data Fig. 6 | Vero E6 and Calu-3 cells were infected with pseudo-SARS-CoV-2-Luc in the presence of vehicle (water) or RBC (500 $\mu$ M). Vero E6 and Calu-3 cells were infected with pseudo-SARS-CoV-2-Luc in the presence of vehicle (water) or RBC $(500 \mu M)$. Luciferase activity was measured at $48 \mathrm{~h}$ post-infection and normalized as $\%$ of the infected cells without any treatment. The results are shown as mean \pm S.D of $n=3$ biologically independent samples. Statistical significance was calculated using an unpaired two-tailed Student's t-test, ${ }^{\star \star} \mathrm{p}<0.01$ using Student's t-test. Grey dashed line represents mean value of the RBC-treated Vero E6 group, which is for easier comparison with that of the RBC-treated Calu-3 group. 


\begin{tabular}{|c|c|c|c|}
\hline Genes & Forward (5' to 3') & Reverse (5' to $\left.3^{\prime}\right)$ & Probe $\left(5^{\prime}\right.$ to $\left.3^{\prime}\right)$ \\
\hline $\begin{array}{l}\text { Hamster } \\
\text { TNF- } \alpha\end{array}$ & $\begin{array}{c}\text { TGA GCC ATC GTG } \\
\text { CCA ATG }\end{array}$ & $\begin{array}{l}\text { AGC CCG TCT } \\
\text { GCT GGT ATC } \\
\text { AC }\end{array}$ & $\begin{array}{c}\text { (6FAM)-CGG CAT GTC TCT } \\
\text { CAA AGA CAA CCA G- } \\
\text { (TAMRA) }\end{array}$ \\
\hline $\begin{array}{l}\text { Hamster } \\
\text { IFN- } \gamma\end{array}$ & $\begin{array}{c}\text { TGT TGC TCT GCC } \\
\text { TCA CTC AGG }\end{array}$ & $\begin{array}{c}\text { AAG ACG AGG } \\
\text { TCC CCT CCA } \\
\text { TTC }\end{array}$ & $\begin{array}{c}\text { (6FAM)- TGG CTG CTA CTG } \\
\text { CCA GGG CAC ACT C- } \\
\text { (TAMRA) }\end{array}$ \\
\hline $\begin{array}{l}\text { Hamster } \\
\text { IL-6* }\end{array}$ & $\begin{array}{c}\text { TGT CTT CTT GGG } \\
\text { ACT GCT GC }\end{array}$ & $\begin{array}{c}\text { CCA AAC CTC } \\
\text { CGA CTT GTT } \\
\text { GA }\end{array}$ & - \\
\hline $\begin{array}{l}\text { Hamster } \\
\text { IL-10 }\end{array}$ & $\begin{array}{l}\text { GGT TGC CAA ACC } \\
\text { TTA TCA GAA ATG }\end{array}$ & $\begin{array}{c}\text { TTC ACC TGT } \\
\text { TCC ACA GCC } \\
\text { TTG }\end{array}$ & $\begin{array}{c}\text { (6FAM) -TGC AGC GCT GTC } \\
\text { ATC GAT TTC TCC C- } \\
\text { (TAMRA) }\end{array}$ \\
\hline $\begin{array}{l}\text { Hamster } \\
\text { CCL22 }\end{array}$ & $\begin{array}{c}\text { TGG TGC CAA CGT } \\
\text { GGA AGA C }\end{array}$ & $\begin{array}{c}\text { GAA GAA CTC } \\
\text { CTT CAC TAC } \\
\text { GCG C }\end{array}$ & $\begin{array}{c}\text { (6FAM)-CTG CTG CCA GGA } \\
\text { CTA CAT CCG TCA GC- } \\
\text { (TAMRA) }\end{array}$ \\
\hline $\begin{array}{c}\text { Hamster } \\
\text { CCR4 }\end{array}$ & $\begin{array}{c}\text { GCT TGG TCA CGT } \\
\text { GGT CAG TG }\end{array}$ & $\begin{array}{c}\text { GTG GTT GCG } \\
\text { CTC CGT GTA G }\end{array}$ & $\begin{array}{c}\text { (6FAM)-TCC CTC CCA GGC } \\
\text { CTC TTG TTC AGC- } \\
\text { (TAMRA) }\end{array}$ \\
\hline $\begin{array}{l}\text { Hamster } \\
\gamma \text {-actin }\end{array}$ & $\begin{array}{c}\text { ACA GAG AGA } \\
\text { AGA TGA CGC } \\
\text { AGA TAA TG }\end{array}$ & $\begin{array}{l}\text { GCC TGA ATG } \\
\text { GCC ACG TAC } \\
\text { A }\end{array}$ & $\begin{array}{c}\text { (VIC)- TTG AAA CCT TCA } \\
\text { ACA CCC CAG CC- } \\
\text { (TAMRA) }\end{array}$ \\
\hline
\end{tabular}

* SYBR Green-based detection without using probe.

Extended Data Fig. 7 | Gene-specific primer and probe sequences for hamster cytokine/chemokine mRNA profiling. List of probes and primers used in qRT-PCR assays. 


\section{Reporting Summary}

Nature Research wishes to improve the reproducibility of the work that we publish. This form provides structure for consistency and transparency in reporting. For further information on Nature Research policies, see our Editorial Policies and the Editorial Policy Checklist.

\section{Statistics}

For all statistical analyses, confirm that the following items are present in the figure legend, table legend, main text, or Methods section.

n/a Confirmed

$\square$ \The exact sample size $(n)$ for each experimental group/condition, given as a discrete number and unit of measurement

$\square$ \ A statement on whether measurements were taken from distinct samples or whether the same sample was measured repeatedly

$\square$ The statistical test(s) used AND whether they are one- or two-sided

$\square$ Only common tests should be described solely by name; describe more complex techniques in the Methods section.

Х $\square$ A description of all covariates tested

Х $\square$ A description of any assumptions or corrections, such as tests of normality and adjustment for multiple comparisons

$\searrow$ A full description of the statistical parameters including central tendency (e.g. means) or other basic estimates (e.g. regression coefficient)

$\bigotimes$ AND variation (e.g. standard deviation) or associated estimates of uncertainty (e.g. confidence intervals)

$\triangle \square$ For null hypothesis testing, the test statistic (e.g. $F, t, r$ ) with confidence intervals, effect sizes, degrees of freedom and $P$ value noted

Qive $P$ values as exact values whenever suitable.

Х $\square$ For Bayesian analysis, information on the choice of priors and Markov chain Monte Carlo settings

Х $\square$ For hierarchical and complex designs, identification of the appropriate level for tests and full reporting of outcomes

Х $\square$ Estimates of effect sizes (e.g. Cohen's $d$, Pearson's $r$ ), indicating how they were calculated

Our web collection on statistics for biologists contains articles on many of the points above.

\section{Software and code}

Policy information about availability of computer code

Data collection Softmax 7.1; Cary WinUV; Agilent 7700x.

Data analysis Sigma plot (SPSS) in an Excel add-in ED50V10; Prism 8.0 (GraphPad Software Inc.);

For manuscripts utilizing custom algorithms or software that are central to the research but not yet described in published literature, software must be made available to editors and reviewers. We strongly encourage code deposition in a community repository (e.g. GitHub). See the Nature Research guidelines for submitting code \& software for further information.

\section{Data}

Policy information about availability of data

All manuscripts must include a data availability statement. This statement should provide the following information, where applicable:

- Accession codes, unique identifiers, or web links for publicly available datasets

- A list of figures that have associated raw data

- A description of any restrictions on data availability

Supplementary Information and Source data are provided with this Article. Additional data that support the findings of this study are available from the corresponding author upon reasonable request (Hongzhe SUN: hsun@hku.hk). 


\section{Field-specific reporting}

Please select the one below that is the best fit for your research. If you are not sure, read the appropriate sections before making your selection. $\bigotimes$ Life sciences $\quad \square$ Behavioural \& social sciences $\square$ Ecological, evolutionary \& environmental sciences

For a reference copy of the document with all sections, see nature.com/documents/nr-reporting-summary-flat.pdf

\section{Life sciences study design}

All studies must disclose on these points even when the disclosure is negative.

Sample size The sample size of $n=5$ each group was chosen for animal studies. For in vitro biochemical studies, three biological repeats, followed by repeating the experiements twice for confirmation were widely accepted and used in published papers.

Data exclusions No data were excluded from the analysis.

Replication $\quad$ All the experiments were subjected to at least three biological replicates unless specified.

Randomization Hamsters were allocated randomly into experimental groups.

Blinding The investigators were not blinded to allocation during experiments and outcome assessment.

\section{Reporting for specific materials, systems and methods}

We require information from authors about some types of materials, experimental systems and methods used in many studies. Here, indicate whether each material, system or method listed is relevant to your study. If you are not sure if a list item applies to your research, read the appropriate section before selecting a response.

\begin{tabular}{l|l} 
Materials \& experimental systems \\
\hline $\mathrm{n} / \mathrm{a}$ & Involved in the study \\
$\square$ & $\bigotimes$ Antibodies \\
$\square$ & $\square$ Eukaryotic cell lines \\
$\square$ & $\square$ Animals and other organisms \\
$\square$ & $\square$ Clinical data
\end{tabular}

\begin{tabular}{l|l} 
Methods \\
\hline n/a & Involved in the study \\
$\square$ & $\square$ ChIP-seq \\
$\square$ & $\square$ Flow cytometry \\
$\searrow$ & $\square$ MRI-based neuroimaging
\end{tabular}

\section{Antibodies}

Antibodies used

Alexa Fluor secondary antibody (Invitrogen, Cat No. \#A32731); rabbit-anti-SARS-CoV-2-NP serum was made in house.

Validation

The antibody is validated for the indicated use by the manufacturer.

\section{Eukaryotic cell lines}

Policy information about cell lines

Cell line source(s)

Human colon epithelial (Caco2) cells, African green monkey kidney (VeroE6) cells and human lung epithelial cell (Calu-3) were purchased from American Type Culture Collection (ATCC).HEK293-hACE2 stable cells were kindly provided by Dr. Li Liu (AIDS Institute, The University of Hong Kong).

Authentication

The cell lines used in this study were not authenticated since they were purchased from commercial source and were extensively validated before shipping.

Mycoplasma contamination

The cell lines used in this study were comfirmed to be free of mycoplasma contamination by PlasmoTest (InvivoGen).

Commonly misidentified lines

(See ICLAC register)

No cell lines used in this study were is listed in ICLAC. 


\section{Animals and other organisms}

Policy information about studies involving animals; ARRIVE guidelines recommended for reporting animal research

Laboratory animals

Male and female Syrian hamsters, aged 6-10 weeks old, were obtained from the Laboratory Animal Unit of The University of Hong Kong. The animals were given access to standard pellet feed and water ad libitum until virus challenge in our Biosafety Level-3 animal facility.

Wild animals

This study did not involve any wild animals.

Field-collected samples

This study did not involve samples collected from the field.

Ethics oversight

All experimental protocols were approved by the Animal Ethics Committee in the University of Hong Kong (CULATR) and were performed according to the standard operating procedures of the biosafety level 3 animal facilities (Reference code: CULATR 5370-20)

Note that full information on the approval of the study protocol must also be provided in the manuscript. 